\title{
HYDROXIDE-PROMOTED CORE CONVERSIONS OF MOLYBDENUM-IRON-SULFUR EDGE-BRIDGED DOUBLE CUBANES: OXYGEN-LIGATED TOPOLOGICAL PN CLUSTERS
}

\author{
Mark L. Hlavinka, Taichi Miyaji, Richard J. Staples, and R. H. Holm ${ }^{*}$ \\ Department of Chemistry and Chemical Biology, Harvard University, Cambridge, Massachusetts \\ 02138
}

\begin{abstract}
The occurence of a heteroatom $\mathrm{X}(\mathrm{C}, \mathrm{N}$, or $\mathrm{O})$ in the $\mathrm{MoFe}_{7} \mathrm{~S}_{9} \mathrm{X}$ core of the iron-molybdenum cofactor of nitrogenase has encouraged synthetic attempts to prepare high nuclearity M-Fe-S-X clusters containing such atoms. We have previously shown that reaction of the edge-bridged double cubane $\left[(\mathrm{Tp})_{2} \mathrm{Mo}_{2} \mathrm{Fe}_{6} \mathrm{~S}_{8}\left(\mathrm{PEt}_{3}\right)_{4}\right]$ (1) with nucleophiles $\mathrm{HQ}^{-}$affords the clusters $\left[(\mathrm{Tp})_{2} \mathrm{Mo}_{2} \mathrm{Fe}_{6} \mathrm{~S}_{8} \mathrm{Q}\right.$ $\left.(\mathrm{QH})_{2}\right]^{3-}(\mathrm{Q}=\mathrm{S}, \mathrm{Se})$ in which $\mathrm{HQ}^{-}$is a terminal ligand and $\mathrm{Q}^{2-}$ is a $\mu_{2}$-bridging atom in the core. Reactions with $\mathrm{OH}$ - used as such or oxygen nucleophiles generated in acetonitrile from $\left(\mathrm{Bu}_{3} \mathrm{Sn}\right)_{2} \mathrm{O}$ or $\mathrm{Me}_{3} \mathrm{SnOH}$ and fluoride were examined. Reaction of 1 with $\mathrm{Et}_{4} \mathrm{NOH}$ in acetonitrile/water generates $\left[(\mathrm{Tp})_{2} \mathrm{Mo}_{2} \mathrm{Fe}_{6} \mathrm{~S}_{9}(\mathrm{OH})_{2}\right]^{3-}(\mathbf{3})$, isolated as $\left[(\mathrm{Tp})_{2} \mathrm{Mo}_{2} \mathrm{Fe}_{6} \mathrm{~S}_{9}(\mathrm{OH})(\mathrm{OC}(=\mathrm{NH}) \mathrm{Me})\left(\mathrm{H}_{2} \mathrm{O}\right)\right]^{3-}$ and shown to have the $\left[\mathrm{Mo}_{2} \mathrm{Fe}_{6}\left(\mu_{2}-\mathrm{S}\right)_{2}\left(\mu_{3}-\mathrm{S}\right)_{6}\left(\mu_{6}-\mathrm{S}\right)\right]$ core topology very similar to the $\mathrm{P}^{\mathrm{N}}$ cluster of nitrogenase. The reaction system $1 / \mathrm{Et}_{4} \mathrm{NOH}$ in acetonitrile/methanol yields the $\mathrm{P}^{\mathrm{N}}$-type cluster $\left[(\mathrm{Tp})_{2} \mathrm{Mo}_{2} \mathrm{Fe}_{6} \mathrm{~S}_{9}(\mathrm{OMe})_{2}\left(\mathrm{H}_{2} \mathrm{O}\right)\right]^{3-}(\mathbf{5})$. The system $\mathbf{1} / \mathrm{Me}_{3} \mathrm{SnOH} / \mathrm{F}^{-}$affords the oxo-bridged double $\mathrm{P}^{\mathrm{N}}$-type cluster $\left\{\left[(\mathrm{Tp})_{2} \mathrm{Mo}_{2} \mathrm{Fe}_{6} \mathrm{~S}_{9}\left(\mu_{2}-\mathrm{O}\right)\right]_{2}\right\}^{5-}(\mathbf{7})$, convertible to the oxidized cluster $\left\{\left[(\mathrm{Tp})_{2} \mathrm{Mo}_{2} \mathrm{Fe}_{6} \mathrm{~S}_{9}\left(\mu_{2}-\mathrm{O}\right)\right]_{2}\right\}^{4-}(\mathbf{6})$, which is prepared independently from $\left[(\mathrm{Tp})_{2} \mathrm{Mo}_{2} \mathrm{Fe}_{6} \mathrm{~S}_{9} \mathrm{~F}_{2}\left(\mathrm{H}_{2} \mathrm{O}\right)\right]^{3-} /\left(\mathrm{Bu}_{3} \mathrm{Sn}\right)_{2} \mathrm{O}$. In the preparations of $\mathbf{3}-\mathbf{5}$ and $\mathbf{7}$, hydroxide liberates sulfide from 1 leading to the formation of $\mathrm{P}^{\mathrm{N}}$-type clusters. Unlike reactions with $\mathrm{HQ}^{-}$, no oxygen atoms are integrated into the core structures of the products. However, the half-dimer composition $\left[\mathrm{Mo}_{2} \mathrm{Fe}_{6} \mathrm{~S}_{9} \mathrm{O}\right]$ relates to the $\mathrm{MoFe}_{7} \mathrm{~S}_{9}$ consitution of the putative native cluster with $\mathrm{X}=\mathrm{O}$. $(\mathrm{Tp}=$ hydrotris(pyrazolyl) borate(1-)).
\end{abstract}

\section{Introduction}

In the course of our research on the synthesis of biologically relevant weak-field heterometaliron sulfur clusters, 1,2 we have prepared two types of high-nuclearity clusters, examples of which are depicted in Figure 1. Edge-bridged double cubane (EDBC) clusters contain the $\mathrm{M}_{2} \mathrm{Fe}_{6} \mathrm{~S}_{8}=\mathrm{M}_{2} \mathrm{Fe}_{6}\left(\mu_{3}-\mathrm{S}\right)_{6}\left(\mu_{4}-\mathrm{S}\right)_{2}$ core $\left(\mathrm{M}=\mathrm{V},{ }^{3,4} \mathrm{Mo},{ }^{5-8} \mathrm{~W}^{9}\right)$ and are precursors to $\mathrm{M}_{2} \mathrm{Fe}_{6} \mathrm{~S}_{9}=\mathrm{M}_{2} \mathrm{Fe}_{6}\left(\mu_{2}-\mathrm{S}\right)_{2}\left(\mu_{3}-\mathrm{S}\right)_{6}\left(\mu_{6}-\mathrm{S}\right)$ clusters $\left(\mathrm{M}=\mathrm{V},{ }^{4} \mathrm{Mo}^{5-8,10}\right)$, which are accessible by core conversion reactions with sulfide. The $\mathrm{M}=$ Mo cluster is formed by the apparent stoichiometry of reaction 1 , in which the isolated product cluster is one electron more oxidized than the initial cluster. These clusters present a core structural topology equivalent to that of the $\mathrm{P}^{\mathrm{N}}$ cluster of nitrogenase $\left(\mathrm{Fe}_{8} \mathrm{~S}_{9}=\mathrm{Fe}_{8}\left(\mu_{2}-\mathrm{S}_{\mathrm{Cys}}\right)_{2}\left(\mu_{3}-\mathrm{S}\right)_{6}\left(\mu_{6}-\mathrm{S}\right)\right),{ }^{11,12}$ with the $\mu_{6}-\mathrm{S}$

$$
\left[(\mathrm{Tp})_{2} \mathrm{Mo}_{2} \mathrm{Fe}_{6} \mathrm{~S}_{8}\left(\mathrm{PEt}_{3}\right)_{4}\right]+3 \mathrm{HS}^{-} \rightarrow\left[(\mathrm{Tp})_{2} \mathrm{Mo}_{2} \mathrm{Fe}_{6} \mathrm{~S}_{9}(\mathrm{SH})_{2}\right]^{3-}+4 \mathrm{PEt}_{3}+1 / 2 \mathrm{H}_{2}
$$

\footnotetext{
*To whom correspondence should be addressed. E-mail: holm@chemistry.harvard.edu.

Supporting Information Available. X-ray crystallographic files in CIF format for the four compounds in Table 1. This material is available free of charge via the Internet at http://pubs.acs.org.
} 
atom a prominent stereochemical feature. ${ }^{4,5,10}$ As such, $\mathrm{P}^{\mathrm{N}}$-type clusters are pertinent to the synthetic problem of nitrogenase cluster synthesis, especially if the $\mathrm{P}^{\mathrm{N}}$ and FeMo-cofactor clusters are antecedental, one to the other. The core composition of FeMoco, ${ }^{13} \mathrm{MoFe}_{7} \mathrm{~S}_{9} \mathrm{X}=$ $\mathrm{MoFe}_{7}\left(\mu_{2}-\mathrm{S}\right)_{3}\left(\mu_{3}-\mathrm{S}\right)_{6}\left(\mu_{6}-\mathrm{X}\right)$, includes an interstitial atom $\mathrm{X}$ detected by $\mathrm{X}$-ray crystallography, which allows $\mathrm{X}=\mathrm{C}, \mathrm{N}$, or O. ${ }^{14}$ Any ultimately successful synthetic approach to FeMoco or a close variant thereof must include at some point introduction of atom X.

In consideration of whether the $\mathrm{M}_{2} \mathrm{Fe}_{6} \mathrm{~S}_{8} \rightarrow \mathrm{M}_{2} \mathrm{Fe}_{6} \mathrm{~S}_{9}$ core conversion might allow inclusion of atom $\mathrm{X}$ in the product cluster, we regard the first issue to be the location of the attacking nucleophile in the product cluster. We have found by use of selenide as a surrogate atom for sulfide in reaction 2 that the attacking nucleophile occupies a $\mu_{2}$-bridging position in

$$
\left[(\mathrm{Tp})_{2} \mathrm{Mo}_{2} \mathrm{Fe}_{6} \mathrm{~S}_{8}\left(\mathrm{PEt}_{3}\right)_{4}\right]+3 \mathrm{HSe}^{-} \rightarrow\left[(\mathrm{Tp})_{2} \mathrm{Mo}_{2} \mathrm{Fe}_{6} \mathrm{~S}_{8} \mathrm{Se}(\mathrm{SeH})_{2}\right]^{3-}+4 \mathrm{PEt}_{3}+1 / 2 \mathrm{H}_{2}
$$

the product cluster, as shown in Figure $1 .{ }^{10}$ The next issue is whether another heteroatom $\mathrm{X}$ can be incorporated in a $\mathrm{P}^{\mathrm{N}}$-type cluster and, if so, at what position. We have addressed this issue in reactions with hydroxide as the nucleophile, and disclose our initial results in this report.

\section{Experimental Section}

\section{Preparation of Compounds}

All reactions and manipulations were performed under a pure nitrogen atmosphere using either Schlenk techniques or an inert atmosphere box. Solvents were passed through an Innovative Technology solvent purification system prior to use. Because of the small scale of the preparations, isolated compounds were not analyzed. They were characterized by physical methods. Structures of the four compounds in Table 1 were determined by X-ray diffraction. Like other single cubane $\mathrm{MoFe}_{3} \mathrm{~S}_{4}$ and EBDC clusters, ${ }^{6,7,10}$ those obtained in this work display distinctive isotropically shifted ${ }^{1} \mathrm{H}$ NMR spectra, fully consistent with solid state structures and satisfactory purity of isolated compounds. Parent ions with isotope distributions consistent with the formulations given were observed in electrospray mass spectra; $\mathrm{m} / \mathrm{z}$ values given are at the center of a set of isotopic mass distributions. In the following preparations, yields are based on the unsolvated formula weights of the cluster compounds. All clusters were isolated as black air-sensitive $\mathrm{Et}_{4} \mathrm{~N}^{+}$salts.

\section{$\left(\mathrm{Et}_{4} \mathrm{~N}\right)_{3}\left[(\mathrm{Tp})_{2} \mathrm{Mo}_{2} \mathrm{Fe}_{6} \mathrm{~S}_{9}(\mathrm{OH})(\mathrm{OC}(=\mathrm{NH}) \mathrm{Me})\left(\mathrm{H}_{2} \mathrm{O}\right)\right]$}

To a suspension of $\left[(\mathrm{Tp})_{2} \mathrm{Mo}_{2} \mathrm{Fe}_{6} \mathrm{~S}_{8}\left(\mathrm{PEt}_{3}\right)_{4}\right]^{5}(50 \mathrm{mg}, 0.030 \mathrm{mmol})$ in $5 \mathrm{~mL}$ of acetonitrile was added $88.2 \mu \mathrm{L}(0.119 \mathrm{mmol})$ of a $1.35 \mathrm{M}$ aqueous solution of $\mathrm{Et}_{4} \mathrm{NOH}$. The reaction mixture was stirred for $18 \mathrm{~h}$ at ambient temperature and filtered. Vapor diffusion of ether into the black filtrate afforded the product as $39 \mathrm{mg}(75 \%)$ of black plate-like crystals. An X-ray structure determination identified the crystalline product as $\left(\mathrm{Et}_{4} \mathrm{~N}\right)_{3}\left[(\mathrm{Tp})_{2} \mathrm{Mo}_{2} \mathrm{Fe}_{6} \mathrm{~S}_{9}(\mathrm{OH})(\mathrm{OC}(=\mathrm{NH})\right.$ $\left.\mathrm{Me})\left(\mathrm{H}_{2} \mathrm{O}\right)\right]$. The ${ }^{1} \mathrm{H}$ NMR spectrum is consistent with the formulation $\left(\mathrm{Et}_{4} \mathrm{~N}\right)_{3}\left[(\mathrm{Tp})_{2} \mathrm{Mo}_{2} \mathrm{Fe}_{6} \mathrm{~S}_{9}(\mathrm{OH})_{2}\right]$ in acetonitrile solution. ${ }^{1} \mathrm{H}$ NMR $\left(\mathrm{CD}_{3} \mathrm{CN}\right.$, anion): $\delta 4.7$ (vbr, BH), 4.89 (2), 6.44 (1), 11.12 (br, 2), 12.52 (1), 13.4 (vbr, 1), 15.14 (2). ES-MS: $m / z 1048.9$ $\left(\left\{\left(\mathrm{Et}_{4} \mathrm{~N}\right)_{3}\left[(\mathrm{Tp}) \mathrm{MoFe}_{3} \mathrm{~S}_{5}\right]\right\}^{+}\right), m / z$ 1651.1 $\left(\left\{\left(\mathrm{Et}_{4} \mathrm{~N}\right)_{3} \mathrm{H}\left[(\mathrm{Tp})_{2} \mathrm{Mo}_{2} \mathrm{Fe}_{6} \mathrm{~S}_{9} \mathrm{O}\right]\right\}^{+}\right), m / z 1798.4$ $\left(\left\{\left(\mathrm{Et}_{4} \mathrm{~N}\right)_{4}\left[(\mathrm{Tp})_{2} \mathrm{Mo}_{2} \mathrm{Fe}_{6} \mathrm{~S}_{9}(\mathrm{OH})_{2}\right]\right\}^{+}\right)$. The dihydroxo cluster can also be generated by the addition of excess $\mathrm{H}_{2} \mathrm{O}$ (100 equiv) and [ $\mathrm{Cp}_{2}{ }_{2} \mathrm{Co}$ ] (1.1 equiv) to 1 equiv of $\left(\mathrm{Et}_{4} \mathrm{~N}\right)_{5}\left\{\left[\left((\mathrm{Tp})_{2} \mathrm{Mo}_{2} \mathrm{Fe}_{6} \mathrm{~S}_{9}\right)\left(\mu_{2}-\mathrm{O}\right)\right]_{2}\right\}$ in an acetonitrile solution and stirring for $1 \mathrm{~h}$. $\left[(\mathrm{Tp})_{2} \mathrm{Mo}_{2} \mathrm{Fe}_{6} \mathrm{~S}_{9}(\mathrm{OH})_{2}\right]^{3-}$ was formed in situ in quantitative yield based on ${ }^{1} \mathrm{H}$ NMR spectroscopy. 


\section{$\left(\mathrm{Et}_{4} \mathrm{~N}\right)_{3}\left[(\mathrm{Tp})_{2} \mathrm{Mo}_{2} \mathrm{Fe}_{6} \mathrm{~S}_{9}(\mathrm{OMe})_{2}\left(\mathrm{H}_{2} \mathrm{O}\right)\right]$}

To a suspension of $50 \mathrm{mg}(0.030 \mathrm{mmol})$ of $\left[(\mathrm{Tp})_{2} \mathrm{Mo}_{2} \mathrm{Fe}_{6} \mathrm{~S}_{8}\left(\mathrm{PEt}_{3}\right)_{4}\right]$ in $5 \mathrm{~mL}$ of acetonitrile was added $79.2 \mu \mathrm{L}(0.12 \mathrm{mmol})$ of a $1.50 \mathrm{M}$ solution of $\mathrm{Et}_{4} \mathrm{NOH}$ in $\mathrm{MeOH}$. The reaction mixture was stirred for $18 \mathrm{~h}$ at ambient temperature and filtered. Vapor diffusion of ether into the black filtrate afforded the product as $38 \mathrm{mg}(73 \%)$ of black plate-like crystals.

\section{$\left(\mathrm{Et}_{4} \mathrm{~N}\right)_{4}\left\{\left[\left((\mathrm{Tp})_{2} \mathrm{Mo}_{2} \mathrm{Fe}_{6} \mathrm{~S}_{9}\right)\left(\mu_{2}-\mathrm{O}\right)\right]_{2}\right\}$}

$\left(\mathrm{Et}_{4} \mathrm{~N}\right)_{3}\left[(\mathrm{Tp})_{2} \mathrm{Mo}_{2} \mathrm{Fe}_{6} \mathrm{~S}_{9} \mathrm{~F}_{2}\left(\mathrm{H}_{2} \mathrm{O}\right)\right]^{7}(40 \mathrm{mg}, 0.024 \mathrm{mmol})$ was dissolved in acetonitrile $(7 \mathrm{~mL})$. To this solution was added a solution of $\left(\mathrm{Bu}_{3} \mathrm{Sn}\right)_{2} \mathrm{O}(20 \mathrm{mg}, 0.034 \mathrm{mmol})$ in acetonitrile $(0.4$ $\mathrm{mL})$ and THF $(0.6 \mathrm{~mL})$. The reaction mixture was stirred for $3 \mathrm{~h}$ and filtered. Slow diffusion of ether into the filtrate caused separation of the product as $30 \mathrm{mg}(82 \%)$ of a black crystalline solid. ${ }^{1} \mathrm{H}$ NMR ( $\mathrm{CD}_{3} \mathrm{CN}$, anion): $\delta 4.2$ (vbr, BH), 4.86 (1), 6.17 (2), 7.26 (br, 2), 10.02 (br, 1), 10.92 (2), 12.71 (1). ESMS: $m / z 1520.6\left(\left\{\left(\mathrm{Et}_{4} \mathrm{~N}\right)_{2}\left[(\mathrm{Tp})_{2} \mathrm{Mo}_{2} \mathrm{Fe}_{6} \mathrm{~S}_{9} \mathrm{O}\right]\right\}^{+}\right)$. The title compound can also be generated by the reaction of 1 equiv each of $\left[\mathrm{C}_{7} \mathrm{H}_{7}\right]\left[\mathrm{BF}_{4}\right]$ and $\left(\mathrm{Et}_{4} \mathrm{~N}\right)_{5}\left\{\left[\left((\mathrm{Tp})_{2} \mathrm{Mo}_{2} \mathrm{Fe}_{6} \mathrm{~S}_{9}\right)\left(\mu_{2}-\mathrm{O}\right)\right]_{2}\right\}$ in acetonitrile solution. ${ }^{1} \mathrm{H} \mathrm{NMR}$ spectroscopy reveals the complete oxidation to the [4-] cluster in $1 \mathrm{~h}$.

\section{$\left(\mathrm{Et}_{4} \mathrm{~N}\right)_{5}\left\{\left[\left((\mathrm{Tp})_{2} \mathrm{Mo}_{2} \mathrm{Fe}_{6} \mathrm{~S}_{9}\right)\left(\mu_{2}-\mathrm{O}\right)\right]_{2}\right\}$}

$\left[(\mathrm{Tp})_{2} \mathrm{Mo}_{2} \mathrm{Fe}_{6} \mathrm{~S}_{8}\left(\mathrm{PEt}_{3}\right)_{4}\right](100 \mathrm{mg}, 0.059 \mathrm{mmol}), \mathrm{Et}_{4} \mathrm{NF} \cdot 2 \mathrm{H}_{2} \mathrm{O}(45 \mathrm{mg}, 0.24 \mathrm{mmol})$ and $\mathrm{Me}_{3} \mathrm{SnOH}(43 \mathrm{mg}, 0.24 \mathrm{mmol})$ were combined in acetonitrile $(10 \mathrm{~mL})$. The reaction mixture was stirred for $18 \mathrm{~h}$ at ambient temperature and filtered. Vapor diffusion of ether into the black filtrate afforded the product as $59 \mathrm{mg}(62 \%)$ of black plate-like crystals. ${ }^{1} \mathrm{H} N \mathrm{NR}\left(\mathrm{CD}_{3} \mathrm{CN}\right.$, anion): $\delta 4.7$ (br, BH), 5.38 (2), 5.43 (1), 9.25 (vbr, 1), 10.75 (br, 2), 12.31 (1), 13.01 (2). The title compound can also be generated by the addition of 1.1 equiv of $\left[\mathrm{Cp}_{2}{ }_{2} \mathrm{Co}\right]$ to 1 equiv of $\left(\mathrm{Et}_{4} \mathrm{~N}\right)_{4}\left\{\left[\left((\mathrm{Tp})_{2} \mathrm{Mo}_{2} \mathrm{Fe}_{6} \mathrm{~S}_{9}\right)\left(\mu_{2}-\mathrm{O}\right)\right]_{2}\right\}$ in an acetonitrile solution and stirring for $2 \mathrm{~h}$. ${ }^{1} \mathrm{H}$ NMR spectroscopy revealed complete conversion to the [5-] cluster. This cluster is also generated quantatively by dissolution of crystalline $\left(\mathrm{Et}_{4} \mathrm{~N}\right)_{3}\left[(\mathrm{Tp})_{2} \mathrm{Mo}_{2} \mathrm{Fe}_{6} \mathrm{~S}_{9}(\mathrm{OH})(\mathrm{OC}(=\mathrm{NH}) \mathrm{Me})\left(\mathrm{H}_{2} \mathrm{O}\right)\right]$ in acetonitrile solution. The dimeric product is formed via a condensation reaction of two dihydroxo clusters.

\section{$\left(\mathrm{Et}_{4} \mathrm{~N}\right)_{5}\left\{\left[\left((\mathrm{Tp})_{2} \mathrm{Mo}_{2} \mathrm{Fe}_{6} \mathrm{~S}_{9}\right)\left(\mu_{2}-\mathrm{S}\right)\right]_{2}\right\}$}

$\left(\mathrm{Et}_{4} \mathrm{~N}\right)_{5}\left\{\left[\left((\mathrm{Tp})_{2} \mathrm{Mo}_{2} \mathrm{Fe}_{6} \mathrm{~S}_{9}\right)\left(\mu_{2}-\mathrm{O}\right)\right]_{2}\right\}(20 \mathrm{mg}, 0.0062 \mathrm{mmol})$ and $\left(\mathrm{Me}_{3} \mathrm{Si}\right)_{2} \mathrm{~S}(2.6 \mu \mathrm{L}, 0.012$ $\mathrm{mmol}$ ) were combined in acetonitrile $(3 \mathrm{~mL})$. The reaction mixture was stirred for $1 \mathrm{~h}$ at ambient temperature. The ${ }^{1} \mathrm{H}$ NMR spectrum of the reaction mixture revealed complete conversion to $\left(\mathrm{Et}_{4} \mathrm{~N}\right)_{5}\left\{\left[\left((\mathrm{Tp})_{2} \mathrm{Mo}_{2} \mathrm{Fe}_{6} \mathrm{~S}_{9}\right)\left(\mu_{2}-\mathrm{S}\right)\right]_{2}\right\}$, which was identified by comparison with an authentic sample. ${ }^{10}$

\section{X-ray Structure Determinations}

The structures of the four compounds in Table 1 were determined. Suitable crystals of a solvated form of $\left(\mathrm{Et}_{4} \mathrm{~N}\right)_{3}[4]$ were acquired by ether diffusion into a 50:1 acetonitrile/water (v/ v) solution at room temperature. Crystals of solvated $\left(\mathrm{Et}_{4} \mathrm{~N}\right)_{3}[\mathbf{5}]$ were obtained by either diffusion into a 50:1 acetonitrile/methanol (v/v) solution at room tempareature. Crystals of $\left(\mathrm{Et}_{4} \mathrm{~N}\right)_{4}[6] \cdot 7 \mathrm{MeCN}$ were obtained by the cooling of a concentrated acetonitrile solution to 243 $\mathrm{K}$. Crystals of $\left(\mathrm{Et}_{4} \mathrm{~N}\right)_{5}[7] \cdot 7 \mathrm{MeCN}$ were grown by ether diffusion into an acetonitrile solution at room temperature. Crystals were coated with paratone-N oil and mounted on a Bruker APEX CCD-based diffactometer equipped with an Oxford 700 low-temperature apparatus operating at $193 \mathrm{~K}$ for compounds $\left(\mathrm{Et}_{4} \mathrm{~N}\right)_{3}[\mathbf{5}],\left(\mathrm{Et}_{4} \mathrm{~N}\right)_{4}[\mathbf{6}]$, and $\left(\mathrm{Et}_{4} \mathrm{~N}\right)_{5}[7]$ and $173 \mathrm{~K}$ for compound $\left(\mathrm{Et}_{4} \mathrm{~N}\right)_{3}[4]$. Data were collected with scans of $0.3 \mathrm{~s} /$ frame for $45 \mathrm{~s}$, so that 1271-1850 frames were collected for a hemisphere of data for $\left(\mathrm{Et}_{4} \mathrm{~N}\right)_{3}[\mathbf{5}],\left(\mathrm{Et}_{4} \mathrm{~N}\right)_{4}[\mathbf{6}]$, and $\left(\mathrm{Et}_{4} \mathrm{~N}\right)_{5}[7]$; data for $\left(\mathrm{Et}_{4} \mathrm{~N}\right)_{3}[4]$ were collected with scans of $0.3 \mathrm{~s} /$ frame for $45 \mathrm{~s}$. The first 50 frames were recollected at the end of the data collection to monitor for decay; no significant decay was 
detected for any compound. Cell parameters were retrieved with SMART software and refined using SAINT software on all reflections. Data integration was performed with SAINT, which corrects for Lorenz polarization and decay. Absorption corrections were applied using SADABS. Space groups were assigned unambiguously by analysis of symmetry and systematic absences determined by XPREP.

All structures were solved and refined using SHELXTL software supplied by Bruker. $\left(\mathrm{Et}_{4} \mathrm{~N}\right)_{3}[\mathbf{4}]$ was refined in space group $P 2_{1} 2_{1} 2_{1}(19)$ with four and one-half acetonitrile solvate molecules and two water molecules (one of which is disordered over two sites). The hydrogen atoms on the water molecules were not modeled. The crystal was refined as a racemic twin with the twin parameters refining to 0.22 , suggesting a $22 \%$ racemic crystal. One cation was constrained to standard angles and distances because its potential disorder could not be successfully modeled. $\left(\mathrm{Et}_{4} \mathrm{~N}\right)_{3}[\mathbf{5}]$ was refined in space group $P 2_{1} / m$ (11) with two acetonitrile and one water solvate molecules on the mirror plane and five methanol solvate molecules either disordered or residing on or across the mirror plane. $\left(\mathrm{Et}_{4} \mathrm{~N}\right)_{4}[\mathbf{6}]$ was refined in space group $P 2_{1} / m$ with seven acetonitrile solvate molecules, which were constrained to reasonable bond lengths and angles. $\left(\mathrm{Et}_{4} \mathrm{~N}\right)_{5}[7]$ was refined in space group $P(2)$ with seven acetonitrile solvate molecules, which are disordered. One cation was also found to be disordered. Final crystal parameters and agreement factors are reported in Table 1.15

\section{Other Physical Measurements}

All measurements were performed under anaerobic conditions. ${ }^{1} \mathrm{H}$ NMR spectra were obtained with a Varian AM-400 spectrometer. Electrochemical measurements were made with a Princeton Applied Research model 263 potentiostat/galvanostat using acetonitrile solutions, a glassy carbon working electrode, and $0.1 \mathrm{M}\left(\mathrm{Bu}_{4} \mathrm{~N}\right)\left(\mathrm{PF}_{6}\right)$ supporting electrolyte. Potentials are referenced to a standard calomel electrode (SCE). Electrospray mass spectra were recorded on acetonitrile solutions $(10 \mathrm{mM})$ directly infused into a LCT mass spectrometer at a flow rate of $5 \mu \mathrm{L} / \mathrm{min} .{ }^{57} \mathrm{Fe}$ Mössbauer spectra were recorded with a constant acceleration spectrometer. Data were analyzed using WMOSS software (WEB Research Corp., Edina, MN). The spectra consist of a single quadrupole doublet of varying linewidths and no additional resolved structure, and were fitted as a single doublet. Isomer shifts are referenced to iron metal at room temperature.

In the following sections, clusters are designated according to the Chart.

\section{Results and Discussion}

Recently, we reported that upon treatment with 4 equiv of $\mathrm{Et}_{4} \mathrm{NF} \cdot 2 \mathrm{H}_{2} \mathrm{O}$ the all-ferrous phosphine-ligated EBDC 1 was converted to a 2:1 mixture of EBDC $\left[(\mathrm{Tp})_{2} \mathrm{Mo}_{2} \mathrm{Fe}_{6} \mathrm{~S}_{8} \mathrm{~F}_{4}\right]^{3-}$ and the $\mathrm{P}^{\mathrm{N}}$-type difluoride cluster $2 .{ }^{7}$ The apparent stoichiometry leading to $\mathbf{2}$ is indicated in reaction 3. Addition of $\left(\mathrm{Me}_{3} \mathrm{Si}\right)_{2} \mathrm{~S}$ to the mixture resulted in complete conversion of $\left[(\mathrm{Tp})_{2} \mathrm{Mo}_{2} \mathrm{Fe}_{6} \mathrm{~S}_{8} \mathrm{~F}_{4}\right]^{3-}$ to 2 , a reaction favored by the $\mathrm{ca} .40-50 \mathrm{kcal} / \mathrm{mol}$ difference between Si-F and Si-S bond energies. ${ }^{16,17}$ This observation raised the possibility that atoms other than

$$
\left[(\mathrm{Tp})_{2} \mathrm{Mo}_{2} \mathrm{Fe}_{6} \mathrm{~S}_{8}\left(\mathrm{PEt}_{3}\right)_{4}\right]+4 \mathrm{~F}^{-}+\mathrm{H}_{2} \mathrm{O}+\left(\mathrm{Me}_{3} \mathrm{Si}\right)_{2} \mathrm{~S} \rightarrow\left[(\mathrm{Tp})_{2} \mathrm{Mo}_{2} \mathrm{Fe}_{6} \mathrm{~S}_{9} \mathrm{~F}_{2}\left(\mathrm{H}_{2} \mathrm{O}\right)\right]^{3-}+2 \mathrm{Me}_{3} \mathrm{SiF}+4 \mathrm{Et}_{3} \mathrm{P}+\mathrm{e}^{-}
$$

sulfide or selenide might be incorporated in cluster cores by use of reactants forming products with Si-F or Sn-F bonds, whose strengths exceed those of $\mathrm{Si}-\mathrm{X}$ or $\mathrm{Sn}-\mathrm{X}$ bonds with $\mathrm{X}=\mathrm{O}$ or N. Reactions using oxygen nucleophiles have been examined in the scheme of Figure 2, which includes the formation and structure of cluster $2{ }^{7}$ Because reactions $1-3$ and several others that follow involve oxidation-reduction, we summarize for convenience metal oxidation states (4) in pertinent core oxidation states of clusters. These follow from ${ }^{57} \mathrm{Fe}$ isomer shifts averaged 
over six iron atoms in electronically delocalized clusters. $5,7,18,19$ Selected structural parameters for product clusters in Figure 2 are collected in Table 2

$$
\begin{array}{ll}
{\left[\mathrm{Mo}_{2} \mathrm{Fe}_{6} \mathrm{~S}_{8}\right]^{2+}} & 6 \mathrm{Fe}^{2+} \\
{\left[\mathrm{Mo}_{2} \mathrm{Fe}_{6} \mathrm{~S}_{9}\right]^{1+}} & 5 \mathrm{Fe}^{2+}+\mathrm{Fe}^{3+} \\
{\left[\mathrm{Mo}_{2} \mathrm{Fe}_{6} \mathrm{~S}_{9}\right]^{2+}} & 4 \mathrm{Fe}^{2+}+2 \mathrm{Fe}^{3+}
\end{array}
$$

\section{Reactions with Hydroxide: Single $\mathbf{P}^{\mathrm{N}}$-Type Clusters}

Treatment of 1 with 4 equiv of $\mathrm{Et}_{4} \mathrm{NOH}$ in $c a .50: 1$ acetonitrile/water (v/v) results in the formation of a species that exhibits two sets of isotropically shifted pyrazolyl ${ }^{1} \mathrm{H}$ NMR signals in an intensity ratio of 2:1. The spectrum, provided in Figure 3, is consistent with a species of $C_{S}$ symmetry that is assigned as the dihydroxo cluster 3 . The spectrum is similar to that of the $\mathrm{P}^{\mathrm{N}}$-type cluster $\left[(\mathrm{Tp})_{2} \mathrm{Mo}_{2} \mathrm{Fe}_{6} \mathrm{~S}_{9}(\mathrm{SH})_{2}\right]^{3-}$ (Figure $1 ; \delta 5.14(2), 8.30(1), 11.75(2), 13.31(1)$, $\left.16.30(2), 20.9(\mathrm{br})^{5}\right)$. The cluster formulation is supported by the positive-ion mass spectrum in Figure 4 revealing an isotope distribution pattern centered near $\mathrm{m} / \mathrm{z} 1798.4$ consistent with intact 3 in association with four $\mathrm{Et}_{4} \mathrm{~N}^{+}$cations. Attempted isolation of the cluster by diffusion of ether into an acetonitrile solution afforded black crystals, which were identified by an Xray structure determination as solvated $\left(\mathrm{Et}_{4} \mathrm{~N}\right)_{3}[4]$. As seen in Figure 5, this cluster has idealized mirror symmetry and overall the topology of a $\mathrm{P}^{\mathrm{N}}$-type cluster, most obviously conveyed by the two $\mu_{2}-\mathrm{S}$, six $\mu_{3}-\mathrm{S}$, and one $\mu_{6}-\mathrm{S}$ atom and the large Fe1-( $\left.\mu_{6}-\mathrm{S}\right)-\mathrm{Fe} 6$ angle $\alpha=139.0(1)^{\circ}$. All iron atoms in these and subsequent structures have distorted tetrahedral coordination. Because structures of $\mathrm{P}^{\mathrm{N}}$-type clusters have been described in some detail earlier, ${ }^{4,5}$ similar accounts of the structures reported here are not required because of the small dimensional differences. However, this structure is unusual in having a terminal hydroxo ligand (O1) hydrogen-bonded to a water molecule $(\mathrm{O} 3)$ which in turn forms a $\mathrm{O}-\mathrm{H} \cdots \mathrm{N}$ hydrogen bond with an $\eta^{1}-(\mathrm{MeCONH})^{1-}$ terminal ligand. In this array, the angle O1-O3-N13 $=110.2^{\circ}$. The acetimidate ion presumably arises because of nucleophilic attack of hydroxide on an acetonitrile solvent molecule. Its identification is consistent with the bond distances N13-C19 $=1.22(2) \AA, \mathrm{O} 2-\mathrm{C} 191.33(2) \AA$, and C19-C20 = 1.53(2) $\mathrm{A}$. Bond angles at C19 are 115-126 . The $(\mathrm{RCONH})^{1-}$ ligand is recognized to have a number of monodentate and bidentate binding modes $^{20}$ and to span two metal sites, 21,22 most notably in the platinum blues. ${ }^{23}$

The individual $\mathrm{P}^{\mathrm{N}}$-type structures of clusters $\mathbf{3}$ and $\mathbf{4}$ are likely stabilized by water through hydrogen-bonding interactions. When the black plate-like crystals of $\left(\mathrm{Et}_{4} \mathrm{~N}\right)_{3}[4]$ are treated with acetonitrile and the reaction solution examined by ${ }^{1} \mathrm{H}$ NMR within 5 min, the spectrum of the oxo-bridged double $\mathrm{P}^{\mathrm{N}}$-type cluster 7 (see below) is observed. Addition of $c a$. 100 equiv of water and 1 equiv of $\left[\mathrm{Cp}_{2}{ }_{2} \mathrm{Co}\right]$ to the solution regenerates 3 , consistent with reaction 5 .

$2\left[(\mathrm{Tp})_{2} \mathrm{Mo}_{2} \mathrm{Fe}_{6} \mathrm{~S}_{9}(\mathrm{OH})_{2}\right]^{3-} \rightleftharpoons\left\{\left[(\mathrm{Tp})_{2} \mathrm{Mo}_{2} \mathrm{Fe}_{6} \mathrm{~S}_{9}\left(\mu_{2}-\mathrm{O}\right)\right]_{2}\right\}^{5-}+\mathrm{H}_{2} \mathrm{O}+\mathrm{e}^{-}$

A second reaction between 1 and 4 equiv of $\mathrm{Et}_{4} \mathrm{NOH}$ was conducted in methanol. The product was identified by a structure determination as the solvated $\mathrm{Et}_{4} \mathrm{~N}^{+}$salt of a different $\mathrm{P}^{\mathrm{N}}$-type cluster 5 (Figure 5). This cluster features terminal methoxide ligands $(\mathrm{Fe} 2-\mathrm{O} 1=1.891(8) \AA$, Fe4-O2 1.893(8) $\AA$ ) bridged by a hydrogen bonding water molecule (O3) with the angle O1$\mathrm{O} 3-\mathrm{O} 2=105.9^{\circ}$, and $\alpha=145.4(2)^{\circ}$. The hydrogen bonding interactions are similar to those between a water molecule and two terminal fluoride ligands in $\mathrm{P}^{\mathrm{N}}$-type cluster 2.7

It is evident that with hydroxide as a nucleophile in systems similar to those of reactions 1 and 2 , oxygen is not integrated into the core structure of the isolated product. Instead, by means unclear hydroxide facilitates the liberation of sulfide from initial cluster $\mathbf{1}$ or some intermediate species. The liberated sulfide is incorporated in the core of another cluster, likely $\mathbf{1}$, in an overall process formulated as reaction 6 . As in reactions 1 and 2, one-half equivalent of dihydrogen 
is introduced as the presumptive electron acceptor. Multiple reactions lead to the conclusion that the mol ratio $\mathrm{OH}^{-} / \mathbf{1} \approx 4: 1$ is an empirical near-optimal reaction stoichiometry. Two equivalents of hydroxide are utilized as ligands in the product cluster and the remainder apparently degrade other clusters liberating sulfide. Judging from the $75 \%$ isolated yield of $\left(\mathrm{Et}_{4} \mathrm{~N}\right)_{3}[4]$, one cluster evidently supplies more than one sulfide in product formation.

$$
\left[(\mathrm{Tp})_{2} \mathrm{Mo}_{2} \mathrm{Fe}_{6} \mathrm{~S}_{8}\left(\mathrm{PEt}_{3}\right)_{4}\right]+\mathrm{HS}^{-}+2 \mathrm{OH}^{-} \rightarrow\left[(\mathrm{Tp})_{2} \mathrm{Mo}_{2} \mathrm{Fe}_{6} \mathrm{~S}_{9}(\mathrm{OH})_{2}\right]^{3-}+4 \mathrm{PEt}_{3}+1 / 2 \mathrm{H}_{2}
$$

Clusters $\mathbf{3}$ and $\mathbf{4}$ are the first examples, out of several hundred Fe-S and heterometal weak-field $\mathrm{M}-\mathrm{Fe}-\mathrm{S}$ clusters reported, that contain terminal hydroxide ligands. We have previously reported the preparation and structures of the $\mathrm{P}^{\mathrm{N}}$-type clusters $\left[(\mathrm{Tp})_{2} \mathrm{Mo}_{2} \mathrm{Fe}_{6} \mathrm{~S}_{8}\left(\mu_{2}-\mathrm{OMe}\right)(\mathrm{OMe})_{2}\right]^{3-}$ and $\left[(\mathrm{Tp})_{2} \mathrm{Mo}_{2} \mathrm{Fe}_{6} \mathrm{~S}_{7}\left(\mu_{2}-\mathrm{OMe}\right)_{2}(\mathrm{OMe})_{2}\right]^{3-}$, which present two terminal methoxide ligands. ${ }^{6}$ These are the only instances in which an oxygen atom (albeit as methoxide) resides in the core structure.

\section{Reactions with Tin(IV) Oxides: Doubly Bridged $\mathbf{P}^{\mathrm{N}}$-Type Clusters}

The compounds $\left(\mathrm{Bu}_{3} \mathrm{Sn}\right)_{2} \mathrm{O}$ and $\mathrm{Me}_{3} \mathrm{SnOH}$ have been examined as sources of oxygen nucleophiles in acetonitrile, presumably generated by reaction with fluoride. Using cluster 2 as a precursor, reaction 7 affords the product cluster as a solvated form of $\left(\mathrm{Et}_{4} \mathrm{~N}\right)_{4}[\mathbf{6}](82 \%)$. Like that of $\mathbf{3}$, the ${ }^{1} \mathrm{H}$ NMR spectrum of $\mathbf{6}$ indicates $C_{S}$ symmetry. The cluster structure, set out in Figure 6, is that of a doubly oxo-bridged double $\mathrm{P}^{\mathrm{N}}$-type cluster. This structure type has been previously encountered with $\left\{\left[\left(\mathrm{Cl}_{4} \mathrm{cat}\right)_{2}\left(\mathrm{Et}_{3} \mathrm{P}\right)_{2} \mathrm{Mo}_{2} \mathrm{Fe}_{6} \mathrm{~S}_{9}\left(\mu_{2}-\mathrm{S}\right)\right]_{2} \mathrm{~K}_{3}(\mathrm{DMF})\right\}^{5-18}$ and $\left.\left\{\left[(\mathrm{Tp})_{2} \mathrm{Mo}_{2} \mathrm{Fe}_{6} \mathrm{~S}_{9}\right)\left(\mu_{2}-\mathrm{Q}\right)\right]_{2}\right\}^{5-}\left(\mathrm{Q}=\mathrm{S},{ }^{10} \mathrm{Se}^{5,10}\right)$. The product 4- oxidation state requires a one-electron oxidation of the initial cluster to produce two equivalent $\left[\mathrm{Mo}_{2} \mathrm{Fe}_{6} \mathrm{~S}_{9}\right]^{2+}$ cores. In another reaction, cluster 1 was treated with four equiv each of $\mathrm{Me}_{3} \mathrm{SnOH}$ and fluoride,

$2\left[(\mathrm{Tp})_{2} \mathrm{Mo}_{2} \mathrm{Fe}_{6} \mathrm{~S}_{9} \mathrm{~F}_{2}\left(\mathrm{H}_{2} \mathrm{O}\right)\right]^{3-}+\left(\mathrm{Bu}_{3} \mathrm{Sn}\right)_{2} \mathrm{O} \rightarrow\left\{\left[(\mathrm{Tp})_{2} \mathrm{Mo}_{2} \mathrm{Fe}_{6} \mathrm{~S}_{9}\left(\mu_{2}-\mathrm{O}\right)\right]_{2}\right\}^{4-}+2 \mathrm{Bu}_{3} \mathrm{SnF}+\mathrm{H}_{2} \mathrm{O}+2 \mathrm{e}^{-}$

intended to generate hydroxide $\left(\mathrm{Me}_{3} \mathrm{SnOH}+\mathrm{F}^{-} \rightarrow \mathrm{Me}_{3} \mathrm{SnF}+\mathrm{OH}^{-}\right)$. The product isolated is solvated $\left(\mathrm{Et}_{4} \mathrm{~N}\right)_{5}$ [7], also a doubly bridged double $\mathrm{P}^{\mathrm{N}}$-type cluster (Figure 6). This cluster, having the core units $\left[\mathrm{Mo}_{2} \mathrm{Fe}_{6} \mathrm{~S}_{9}\right]^{2+, 1+}$, is one electron more reduced than $\mathbf{6}$, a probable consequence of the difference in oxidation states of precursor clusters $\mathbf{1}$ and $\mathbf{2}$.

Clusters 6 and 7 are built of two $\mathrm{P}^{\mathrm{N}}$-type clusters linked by oxo bridges such that the central portion of the structure is a $\mathrm{Fe}_{4}\left(\mu_{2}-\mathrm{O}\right)_{2}\left(\mu_{6}-\mathrm{S}\right)_{2}$ ring. The structure of $\mathbf{6}$ is centrosymmetric with $\alpha=141.1(1)^{\circ}$. It contains a planar central ring with nearly linear Fe-O-Fe bridges $\left(175.3(2)^{\circ}\right)$ and average Fe-O and Fe-S bonds of 1.767(3) $\AA$ and 2.419(4) $\AA$, respectively. Cluster 6 is the second $\mathrm{P}^{\mathrm{N}}$-type species isolated in the $\left[\mathrm{Mo}_{2} \mathrm{Fe}_{6} \mathrm{~S}_{9}\right]^{2+}$ oxidation state ${ }^{18}$. In cluster 7 , the individual $\mathrm{P}^{\mathrm{N}}$-type clusters, with $\alpha=135.6(1)^{\circ}$, are not crystallographically distinct although in different oxidation states. They are related by a $C_{2}$ axis which bisects the O1-O1A vector. The two halves of the central ring are folded along this vector at a dihedral angle $\theta=158.3^{\circ}$ leading to the longer bond lengths Fe1-O1 = 1.859(8) $\AA$ and Fe6-O1A = 1.879(9) $\AA$; other bonds within the ring are Fe1-S4 = 2.381(3) $\AA$ and Fe6-S4 = 2.396(3) $\AA$.

The preparation of $\mathbf{7}$ completes a series of isoelectronic doubly bridged double $\mathrm{P}^{\mathrm{N}}$-type clusters with Fe- $\left(\mu_{2}-\mathrm{Q}\right)$-Fe bridges $\left(\mathrm{Q}=\mathrm{O}\left(\mathbf{7}, \theta=158.3^{\circ}, \beta=150.3^{\circ}\right), \mathrm{S}\left(\mathbf{8}, \theta=142.5^{\circ}, \beta=134.7^{\circ}\right),{ }^{10}\right.$ $\left.\operatorname{Se}\left(\boldsymbol{9}, \theta=139.3^{\circ}, \beta=130.7^{\circ}\right)\right) .{ }^{10}$ The values of $\theta$ and bridge angle $\beta=\mathrm{Fe}-\mathrm{Q}-\mathrm{Fe}$ follow the usual periodic trend for atoms $\mathrm{Q}$, while also the larger values for $\mathrm{Q}=\mathrm{O}$ and the linear bridges in the planar ring of $\mathbf{6}$ presumably arise from $\mathrm{Fe}-\mathrm{O} \pi$-bonding contributions. In solution, the clusters are readily distingushed by the ${ }^{1} \mathrm{H}$ NMR spectra (Figure 3 ). The isotropically shifted signals of 6 are quite different from 7 , which is electronically delocalized on the ${ }^{1} \mathrm{H}$ NMR time scale and whose shifts approach those of $\mathbf{3}$, with which it has one core oxidation state in common. 
The positive-ion mass spectrum of $\mathbf{6}$, sampled from acetonitrile solution, reveals a prominent signal corresponding to the half-dimer associated with two cations centered around $\mathrm{m} / \mathrm{z} 1520.6$ (Figure 4).

Cluster 7 is directly linked to cluster 8 by reaction 8 . When 7 was treated with 2 equiv of the sulfide reagent and the reaction is monitored by ${ }^{1} \mathrm{H}$ NMR, conversion was found to be complete in one hour. This reaction is another example of the use of $\left(\mathrm{Me}_{3} \mathrm{Si}\right)_{2} \mathrm{~S}$ as a sulfur transfer agent in oxo-for-sulfido reactions. 24

$$
\left\{\left[(\mathrm{Tp})_{2} \mathrm{Mo}_{2} \mathrm{Fe}_{6} \mathrm{~S}_{9}\left(\mu_{2}-\mathrm{O}\right)\right]_{2}\right\}^{5-}+2\left(\mathrm{Me}_{3} \mathrm{Si}\right)_{2} \mathrm{~S} \rightarrow\left\{\left[(\mathrm{Tp})_{2} \mathrm{Mo}_{2} \mathrm{Fe}_{6} \mathrm{~S}_{9}\left(\mu_{2}-\mathrm{S}\right)\right]_{2}\right\}^{5-}+2\left(\mathrm{Me}_{3} \mathrm{Si}\right)_{2} \mathrm{O}
$$

\section{Oxidation States and Redox Reactions}

If reaction 1 were to proceed without change in oxidation state, the expected product is allferrous $\left[(\mathrm{Tp})_{2} \mathrm{Mo}_{2} \mathrm{Fe}_{6} \mathrm{~S}_{9}(\mathrm{SH})_{2}\right]^{4-}$. As shown elsewhere, ${ }^{10}$ the potential $\mathrm{E}_{1 / 2}{ }^{(4-/ 3-)}=-1.80 \mathrm{~V}$ renders the [4-] cluster an extremely strong reductant. Even under normally rigorous anaerobic conditions maintenance of the fully reduced state is very difficult, such that under the circumstances of isolation the [3-] cluster is obtained. Reaction 2 is the same in this regard $\left(\mathrm{E}_{1 / 2}\left(4-/ 3^{-}\right)=-1.81 \mathrm{~V}\right)$, as is reaction 3 although potential data for the product cluster 2 are not available. A similar situation is encountered with the EBDCs $\left[(\mathrm{Tp})_{2} \mathrm{Mo}_{2} \mathrm{Fe}_{6} \mathrm{~S}_{8} \mathrm{~L}_{4}\right]^{4-}(\mathrm{L}=$ halide, $\mathrm{PhS}^{-} ; \mathrm{E}_{1 / 2}{ }^{(4-/ 3-)}=-1.4$ to $-1.7 \mathrm{~V}$ ), where [4-] clusters have been isolated but are very readily oxidized in solution. These considerations rationalize the formation of the [3-] cluster 3 in reaction 6, which may first generate the unstable [4-] species, and its subsequent isolation as $\mathbf{4}$. The isomer shifts of $\mathbf{4}$ and $\mathbf{5}$, listed in Table 3, are comparable to that of isoelectronic $\left[(\mathrm{Tp})_{2} \mathrm{Mo}_{2} \mathrm{Fe}_{6} \mathrm{~S}_{9}(\mathrm{SH})_{2}\right]^{3-}$ and are consistent with the partially oxidized core $\left[\mathrm{Mo}_{2} \mathrm{Fe}_{6} \mathrm{~S}_{9}\right]^{1+}$ $\left(\mathrm{Fe}^{2.17+}\right)$.

In the absence of oxidation, reactions 5 and 7 would be expected to yield the [6-] double $\mathrm{P}^{\mathrm{N}}$ type clusters containing two $\left[\mathrm{Mo}_{2} \mathrm{Fe}_{6} \mathrm{~S}_{9}\right]^{1+}$ cores. Voltammetry of 7 in acetonitrile reveals a set of four quasireversible reactions, a reduction at $\mathrm{E}_{1 / 2}\left(6-15^{-}\right)=-1.90 \mathrm{~V}$, an oxidation at $\mathrm{E}_{1 / 2}(5-/ 4-)=-1.47 \mathrm{~V}$, and two further oxidations at $-0.90 \mathrm{~V}$ and $-0.71 \mathrm{~V}$. Under the prevailing experimental conditons, the [6-] cluster is untenable owing to adventitious oxidation. While the [5-] cluster 7 has been isolated, it is readily susceptible to oxidation in solution. We have demonstrated clean controlled oxidation to $\mathbf{6}$ with tropylium ion and reduction of $\mathbf{6}$ to $\mathbf{7}$ with $\left[\mathrm{Cp}_{2}{ }_{2} \mathrm{Co}\right]$ (Figure 2). These reactions are monitored by ${ }^{1} \mathrm{H}$ NMR and are complete within one hour. The isomer shift order $\delta(\mathbf{7})>\delta(\mathbf{6})$ (Table 3 ) is consistent with $\mathbf{7}$ being more reduced, although the difference $(0.07 \mathrm{~mm} / \mathrm{s})$ is larger than expected. The spectra of both clusters (not shown) are broadened quadrupole doublets which, as with $\mathbf{4}$ and $\mathbf{5}$, do not resolve $\mathrm{FeS}_{4}$ and $\mathrm{FeS}_{3} \mathrm{O}$ sites.

\section{Summary}

The nucleophiles $\mathrm{HS}^{-}$and $\mathrm{HSe}^{-}$manifest two reactivity functions with EBDC cluster 1: (i) invasion of the $\left[\mathrm{Mo}_{2} \mathrm{Fe}_{6} \mathrm{~S}_{8}\right]^{2+}$ core with concomitant conversion to the $\left[\mathrm{Mo}_{2} \mathrm{Fe}_{6} \mathrm{~S}_{8} \mathrm{Q}\right]^{1+}$ core $(\mathrm{Q}=\mathrm{S}, \mathrm{Se})$ and retention of atom $\mathrm{Q}$ in $\mu_{2}$-bridging positions of the isolated $\mathrm{P}^{\mathrm{N}}$-type clusters; (ii) terminal coordination to two iron atoms forming $\mathrm{Fe}\left(\mu_{3}-\mathrm{S}\right)_{2}\left(\mu_{6}-\mathrm{S}\right)_{6}(\mathrm{QH})$ sites. Under comparable experimental conditions, hydroxide introduced as such or generated from tin(IV) reagents reacts with 1 to liberate sulfide which (instead of hydroxide/oxide) is incorporated into core structures, leading to the formation of $\mathrm{P}^{\mathrm{N}}$-type clusters ${ }^{25} 3,4$, and 7. Function (i) is only partially met because of exclusion of oxygen in the core structure; function (ii) is satisfied. Hydroxide is a feasible $\mu_{2}$-ligand, a less-likely $\mu_{3}$-ligand, and would not occupy a $\mu_{6}$-position. There are numerous structural precedents for $\mu_{3}-\mathrm{O}$, and $\mu_{6}-\mathrm{O}$ oxo bridging with iron. $\left(\mathrm{Bu}_{3} \mathrm{Sn}\right)_{2} \mathrm{O}$ was utilized as a possible source of oxide rather than hydroxide by $\mathrm{Sn}-\mathrm{O}$ bond cleavage with fluoride but it also afforded a double $\mathrm{P}^{\mathrm{N}}$-type cluster with oxo atoms in the bridge 
rather than the core. However, one-half of the double $\mathrm{P}^{\mathrm{N}}$-type cluster, $\mathrm{Mo}_{2} \mathrm{Fe}_{6} \mathrm{~S}_{9} \mathrm{O}$, has the desired stoichiometry $\mathrm{MoFe}_{7} \mathrm{~S}_{9} \mathrm{O}$ of putative FeMoco with $\mathrm{X}=\mathrm{O}$, allowing for the substitution of one iron atom by a molybdenum atom. ${ }^{26}$ A relationship between double and single $\mathrm{P}^{\mathrm{N}}$-type hydroxo/oxo clusters is established by the conversion of $\mathbf{7}$ to $\mathbf{3}$ upon addition of water and a reductant. Manipulation of the oxo-bridged clusters are among current experiments aimed at inclusion of atom X in high-nuclearity Mo-Fe-S cluster cores.

\section{Supplementary Materials}

Refer to Web version on PubMed Central for supplementary material.

\section{Acknowledgements}

This research was supported by NIH Grant 28856 . We thank Drs. T. Scott and C. Tessier for experimental assistance and discussions.

\section{References and Notes}

1. Lee SC, Holm RH. Proc Natl Acad Sci USA 2003;100:3595-3600. [PubMed: 12642670]

2. Lee SC, Holm RH. Chem Rev 2004;104:1135-1157. [PubMed: 14871151]

3. Hauser C, Bill E, Holm RH. Inorg Chem 2002;41:1615-1624. [PubMed: 11896732]

4. Zuo JL, Zhou HC, Holm RH. Inorg Chem 2003:4624-4631. [PubMed: 12870953]

5. Zhang Y, Holm RH. J Am Chem Soc 2003;125:3910-3920. [PubMed: 12656626]

6. Zhang Y, Holm RH. Inorg Chem 2004;43:674-682. [PubMed: 14731029]

7. Berlinguette CP, Miyaji T, Zhang Y, Holm RH. Inorg Chem 2006;45:1997-2007. [PubMed: 16499360]

8. Pesavento RP, Berlinguette CP, Holm RH. Inorg Chem 2007;46:510-516. [PubMed: 17279830]

9. Hong D, Zhang Y, Holm RH. Inorg Chim Acta 2005;358:2303-2313.

10. Berlinguette CP, Holm RH. J Am Chem Soc 2006;128:11993-12000. [PubMed: 16953641]

11. Peters JW, Stowell MHB, Soltis SM, Finnegan MG, Johnson MK, Rees DC. Biochemistry 1997;36:1181-1187. [PubMed: 9063865]

12. Mayer SM, Lawson DM, Gormal CA, Roe SM, Smith BE. J Mol Biol 1999;292:871-891. [PubMed: 10525412]

13. Abbreviations are given in the Chart.

14. Einsle O, Tezcan FA, Andrade SLA, Schmid B, Yoshida M, Howard JB, Rees DC. Science 2002;297:1696-1700. [PubMed: 12215645]

15. See paragraph at the end of this article for Supporting Information available.

16. Basch H. Inorg Chim Acta 1996;252:265-279.

17. Luo, YR. Handbook of Bond Dissociation Energies in Organic Compounds. CRC Press; New York: 2003. p. 298-299.

18. Osterloh F, Achim C, Holm RH. Inorg Chem 2001;40:224-232. [PubMed: 11170527]

19. Fomitchev DV, McLauchlan CC, Holm RH. Inorg Chem 2002;41:958-966. [PubMed: 11849099]

20. Constable, EC. Metals and Ligand Reactivity. VCH Publishers; New York: 1996. p. 65-72.

21. Chavan MY, Lin XQ, Ahsan MQ, Bernal I, Bear JL, Kadish KM. Inorg Chem 1986;25:1281-1288.

22. Mironov YV. Eur J Inorg Chem 1999:997-999.

23. Matsumoto K, Sakai K. Adv Inorg Chem 2000;49:375-427.

24. Donahue JP. Chem Rev 2006;106:4747-4783. [PubMed: 17091934]

25. For another approach to $\mathrm{P}^{\mathrm{N}}$-type cluster synthesis see: Ohki Y, Sunada Y, Honda M, Katada M, Tatsumi K. J Am Chem Soc 2003;125:4052-4053. [PubMed: 12670218]

26. Unsymmetrical clusters with the core $\mathrm{MoFe}_{7} \mathrm{~S}_{9}$ or their potential EBDC precurors $\mathrm{MoFe}_{7} \mathrm{~S}_{8}$ have not yet been prepared. 


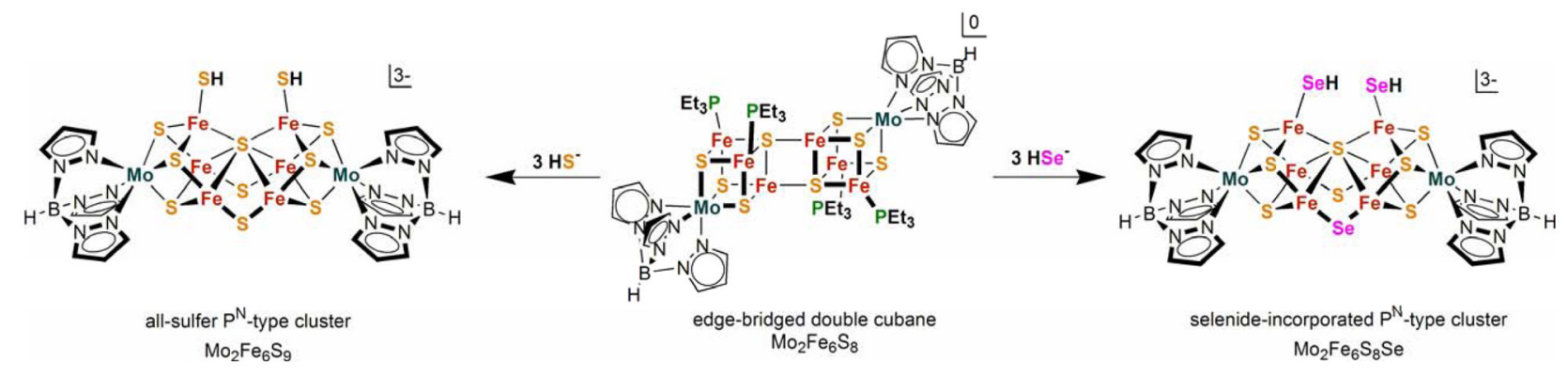

Figure 1. CONVERSION OF EDGE-BRIDGED DOUBLE CUBANE CLUSTER TO SULFIDO AND SELENIDO CONTAINING $\mathbf{P}^{\mathrm{N}}$-TYPE CLUSTERS

Cluster conversion of the edge-bridged double cubane $\left[(\mathrm{Tp})_{2} \mathrm{Mo}_{2} \mathrm{Fe}_{6} \mathrm{~S}_{8}\left(\mathrm{PEt}_{3}\right)_{4}\right]$ to sulfido$\left(\left[(\mathrm{Tp})_{2} \mathrm{Mo}_{2} \mathrm{Fe}_{6} \mathrm{~S}_{9}(\mathrm{SH})_{2}\right]^{3-}\right)$ and selenido-containing $\left(\left[(\mathrm{Tp})_{2} \mathrm{Mo}_{2} \mathrm{Fe}_{6} \mathrm{~S}_{8} \mathrm{Se}(\mathrm{SeH})_{2}\right]^{3-}\right) \mathrm{P}^{\mathrm{N}}$-type clusters. Core compositions are indicated. The attacking nucleophile occupies a $\mu_{2}$ position in the product cluster. 

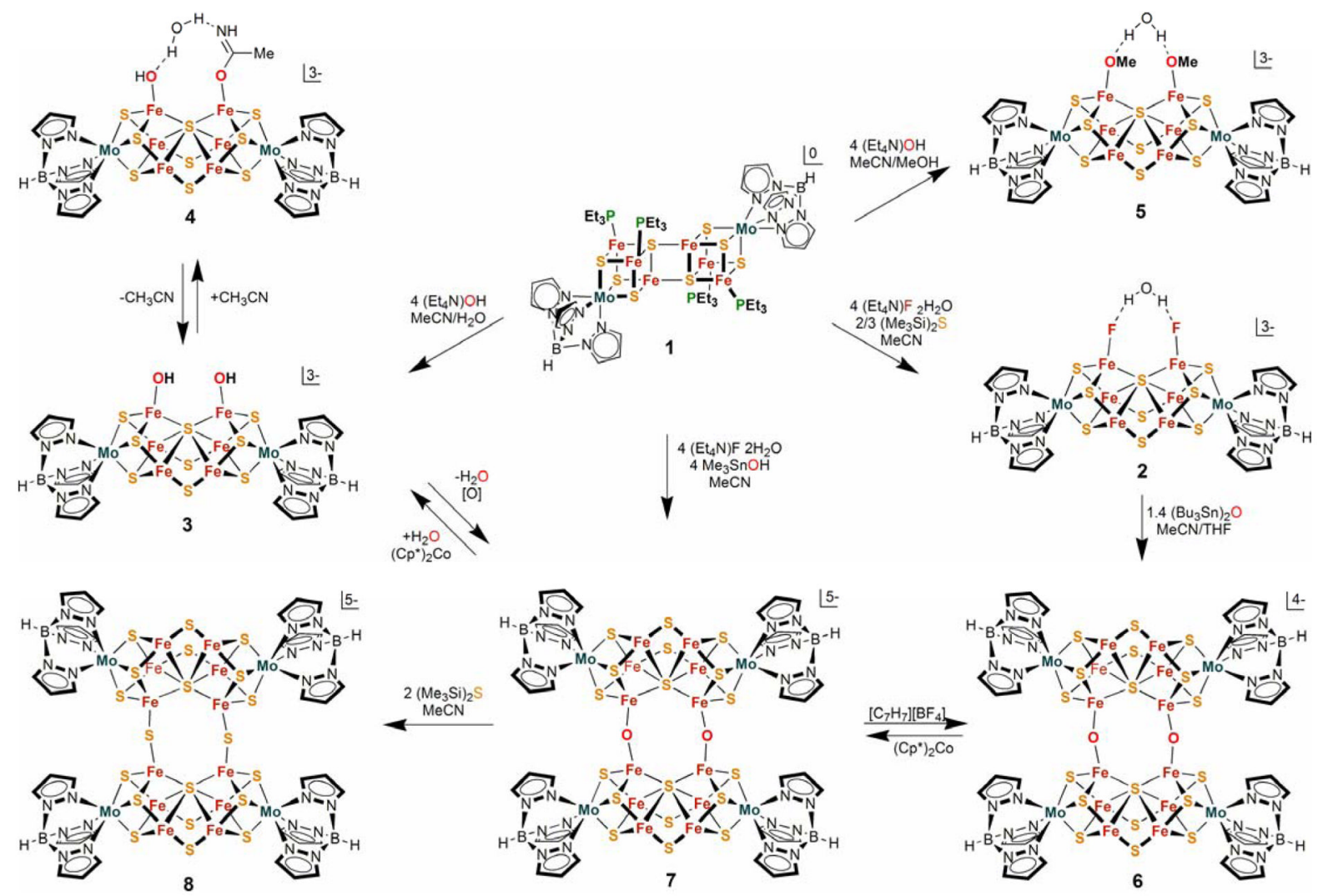

Figure 2. FORMATION AND REACTIONS OF OXO/HYDROXO $\mathrm{P}^{\mathrm{N}}$-TYPE CLUSTERS

Scheme based on cluster 1 depicting reactions leading to $\mathrm{P}^{\mathrm{N}}$-type clusters with terminal methoxide (5) and hydroxide (3) ligands, the formation of oxo-bridged double $\mathrm{P}^{\mathrm{N}}$-type clusters $\mathbf{6}$ and $\mathbf{7}$ from $\mathbf{1}$ and fluoride cluster $\mathbf{2}$, and sulfido-bridged cluster $\mathbf{8}$ from $\mathbf{7}$. 
$\left[(\mathrm{Tp})_{2} \mathrm{Mo}_{2} \mathrm{Fe}_{6} \mathrm{~S}_{9}(\mathrm{OH})_{2}\right]^{3-}$

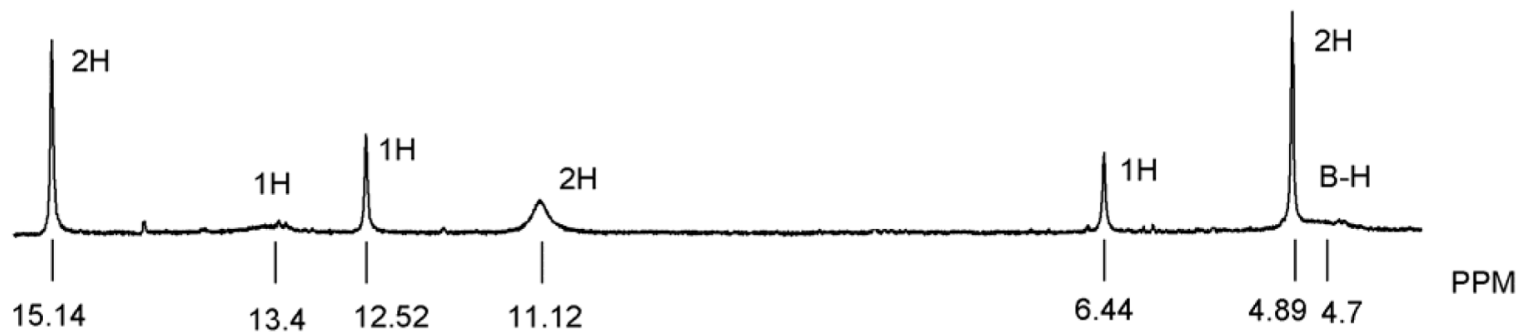

$\left\{\left[\left((\mathrm{Tp})_{2} \mathrm{Mo}_{2} \mathrm{Fe}_{6} \mathrm{~S}_{9}\right)\left(\mu_{2}-\mathrm{O}\right)\right]_{2}\right\}^{4-}$

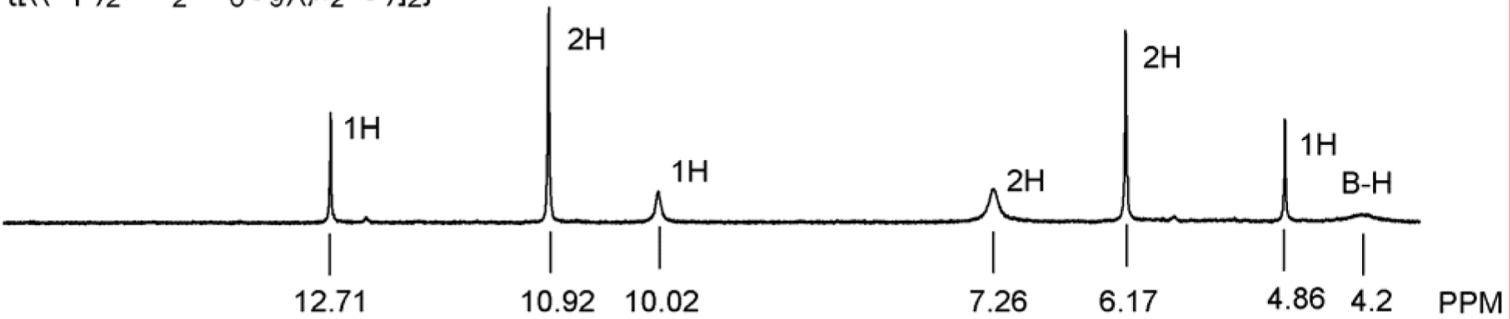

$\left\{\left[\left((\mathrm{Tp})_{2} \mathrm{Mo}_{2} \mathrm{Fe}_{6} \mathrm{~S}_{9}\right)\left(\mu_{2}-\mathrm{O}\right)\right]_{2}\right\}^{5-}$

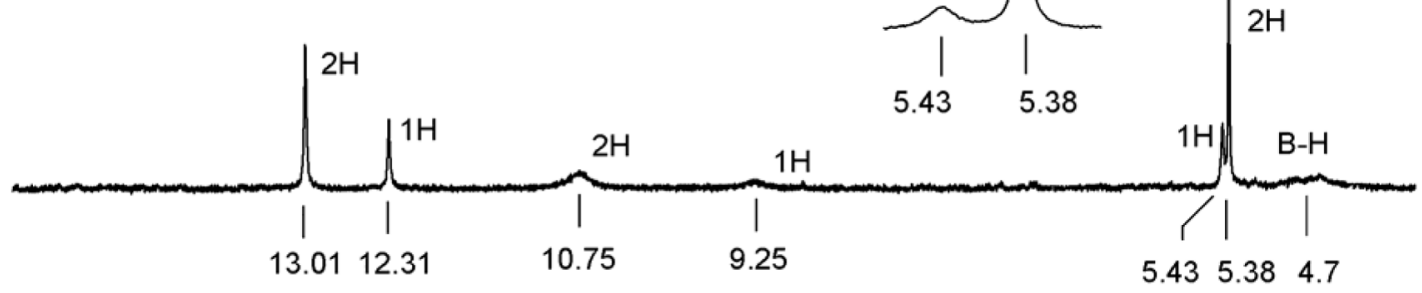

Figure 3.

${ }^{1} \mathrm{H}$ NMR spectra of oxygen-ligated $\mathrm{P}^{\mathrm{N}}$-type clusters: upper, $\left[(\mathrm{Tp})_{2} \mathrm{Mo}_{2} \mathrm{Fe}_{6} \mathrm{~S}_{9}(\mathrm{OH})_{2}\right]^{3-}$, middle, $\left\{\left[\left((\mathrm{Tp})_{2} \mathrm{Mo}_{2} \mathrm{Fe}_{6} \mathrm{~S}_{9}\right)\left(\mu_{2}-\mathrm{O}\right)\right]_{2}\right\}^{4-}$, lower, $\left\{\left[\left((\mathrm{Tp})_{2} \mathrm{Mo}_{2} \mathrm{Fe}_{6} \mathrm{~S}_{9}\right)\left(\mu_{2}-\mathrm{O}\right)\right]_{2}\right\}^{5-}$. Relative signal intensities are indicated. 


\section{$\left\{\left(\mathrm{Et}_{4} \mathrm{~N}\right)_{4}\left[(\mathrm{Tp})_{2} \mathrm{Mo}_{2} \mathrm{Fe}_{6} \mathrm{~S}_{9}(\mathrm{OH})_{2}\right]\right\}^{+}$}

\section{$\left\{\left(\mathrm{Et}_{4} \mathrm{~N}\right)_{2}\left[(\mathrm{Tp})_{2} \mathrm{Mo}_{2} \mathrm{Fe}_{6} \mathrm{~S}_{9} \mathrm{O}\right]\right\}^{+}$}
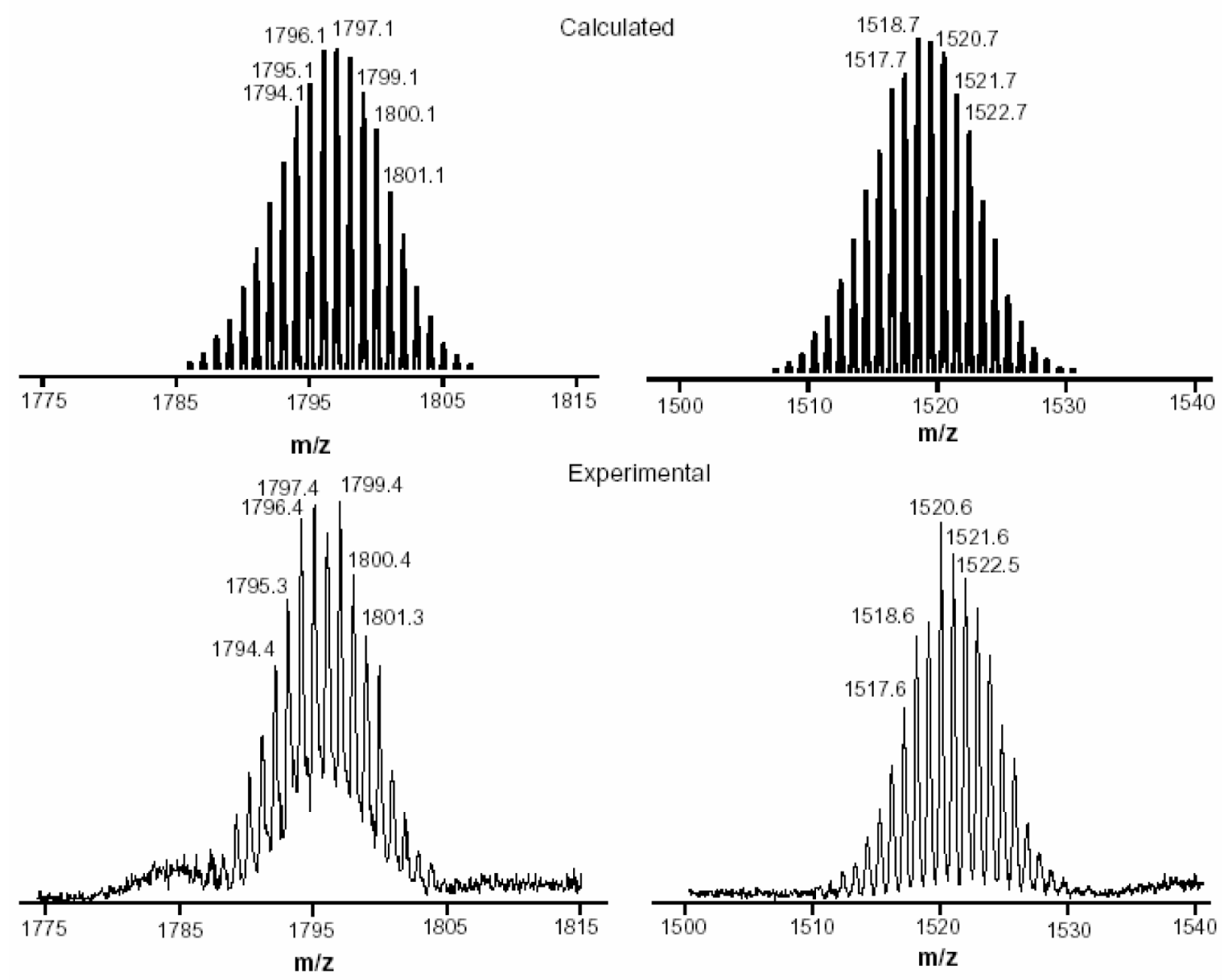

Figure 4. EXPERIMENTAL AND CALCULATED ELECTROSPRAY MASS SPECTRA CONTAINING INTACT OXO/HYDROXO CLUSTERS

Experimental and calculated electrospray mass spectra of $\mathrm{P}^{\mathrm{N}}$-type clusters: upper, $\left\{\left(\mathrm{Et}_{4} \mathrm{~N}\right)_{4}\left[(\mathrm{Tp})_{2} \mathrm{Mo}_{2} \mathrm{Fe}_{6} \mathrm{~S}_{9}(\mathrm{OH})_{2}\right]\right\}^{+}$from $\left(\mathrm{Et}_{4} \mathrm{~N}\right)_{3}\left[(\mathrm{Tp})_{2} \mathrm{Mo}_{2} \mathrm{Fe}_{6} \mathrm{~S}_{9}(\mathrm{OH})_{2}\right]$; lower, $\left\{\left(\mathrm{Et}_{4} \mathrm{~N}\right)_{2} \mathrm{H}\right.$ $\left.\left[(\mathrm{Tp})_{2} \mathrm{Mo}_{2} \mathrm{Fe}_{6} \mathrm{~S}_{9} \mathrm{O}\right]\right\}^{+}$from $\left(\mathrm{Et}_{4} \mathrm{~N}\right)_{4}\left\{\left[(\mathrm{Tp})_{2} \mathrm{Mo}_{2} \mathrm{Fe}_{6} \mathrm{~S}_{9}\left(\mu_{2}-\mathrm{O}\right)\right]_{2}\right\}$. 


\section{$\left[(\mathrm{Tp})_{2} \mathrm{Mo}_{2} \mathrm{Fe}_{6} \mathrm{~S}_{9}(\mathrm{OH})(\mathrm{OC}(=\mathrm{NH}) \mathrm{Me})\left(\mathrm{H}_{2} \mathrm{O}\right)\right]^{3-}$}

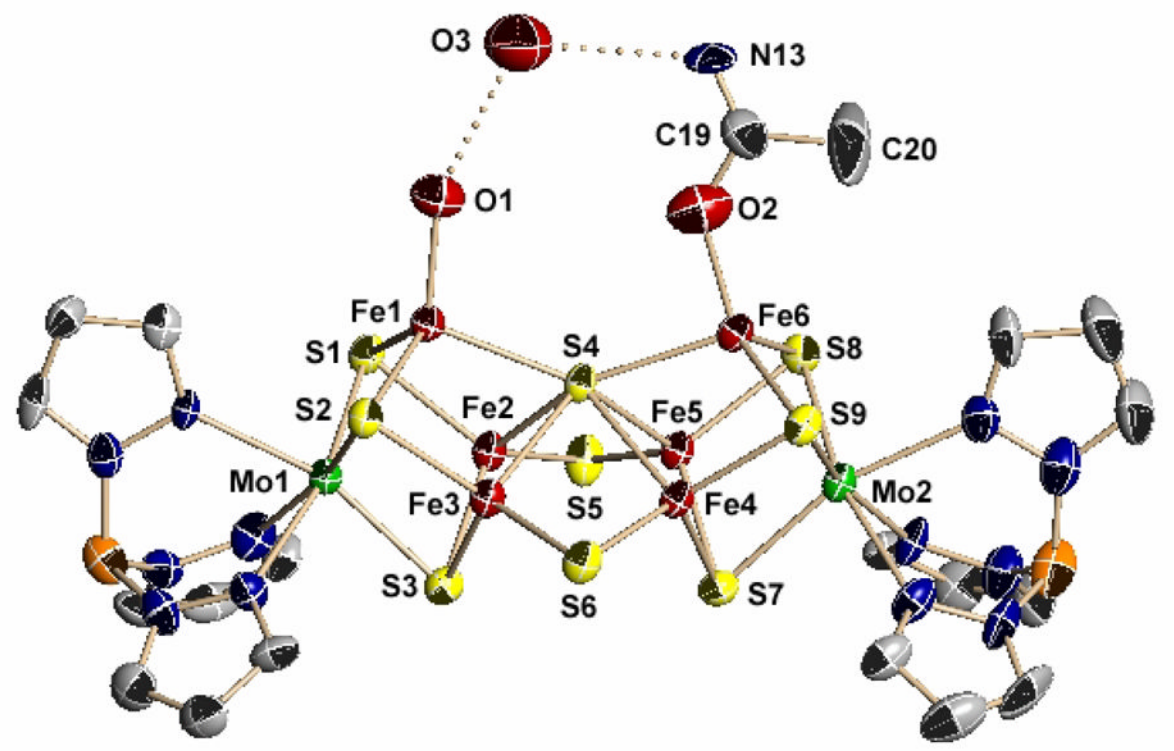

$\left[(\mathrm{Tp})_{2} \mathrm{Mo}_{2} \mathrm{Fe}_{6} \mathrm{~S}_{9}(\mathrm{OMe})_{2}\left(\mathrm{H}_{2} \mathrm{O}\right)\right]^{3-}$

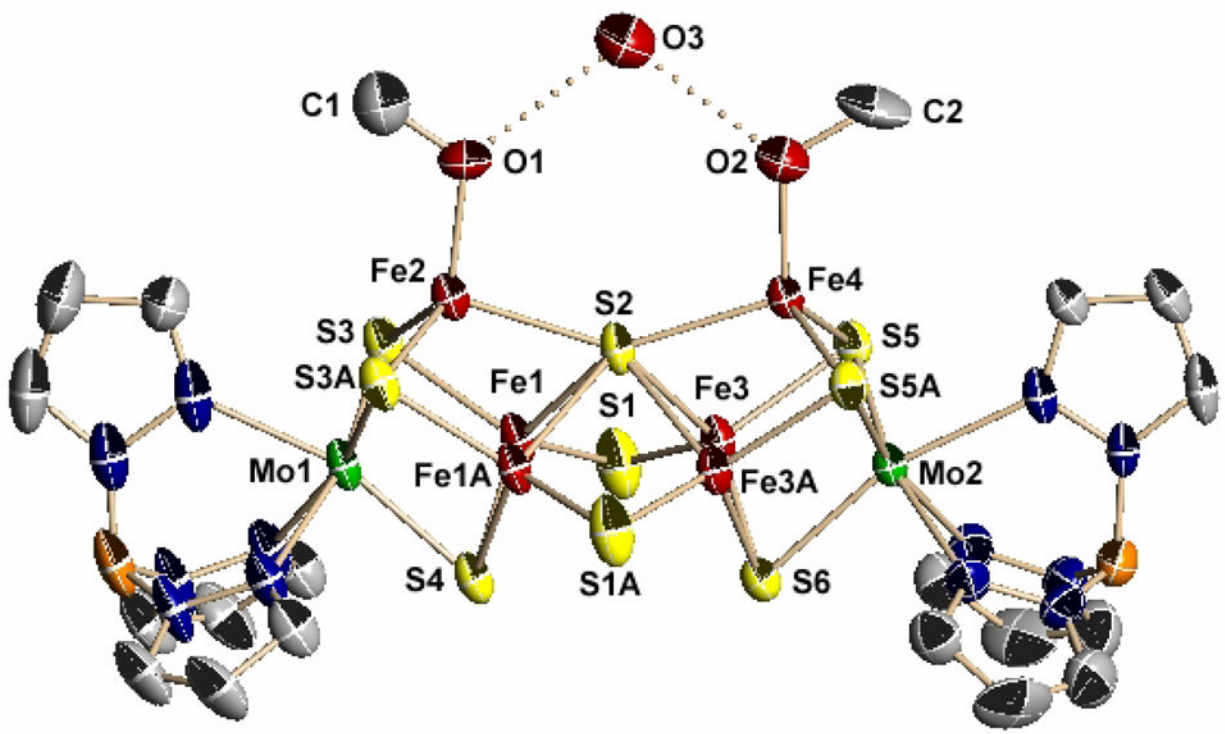

Figure 5.

Structures of $\mathrm{P}^{\mathrm{N}}$-type clusters showing $50 \%$ probability ellipsoids and atom numbering schemes. Upper: $\left[(\mathrm{Tp})_{2} \mathrm{Mo}_{2} \mathrm{Fe}_{6} \mathrm{~S}_{9}(\mathrm{OH})(\mathrm{OC}(=\mathrm{NH}) \mathrm{Me})\left(\mathrm{H}_{2} \mathrm{O}\right)\right]^{3-}$. Lower:

$\left[(\mathrm{Tp})_{2} \mathrm{Mo}_{2} \mathrm{Fe}_{6} \mathrm{~S}_{9}(\mathrm{OMe})_{2}\left(\mathrm{H}_{2} \mathrm{O}\right)\right]^{3-}$ in which atoms $\mathrm{n}$ and $\mathrm{nA}$ are related by a crystallograpically imposed mirror plane. Both clusters contain a water molecule $(\mathrm{O} 3)$ hydrogen-bonded to the terminal ligands. 


\section{$\left\{\left[(\mathrm{Tp})_{2} \mathrm{Mo}_{2} \mathrm{Fe}_{6} \mathrm{~S}_{9} \mathrm{O}\right]_{2}\right\}^{4-}$}
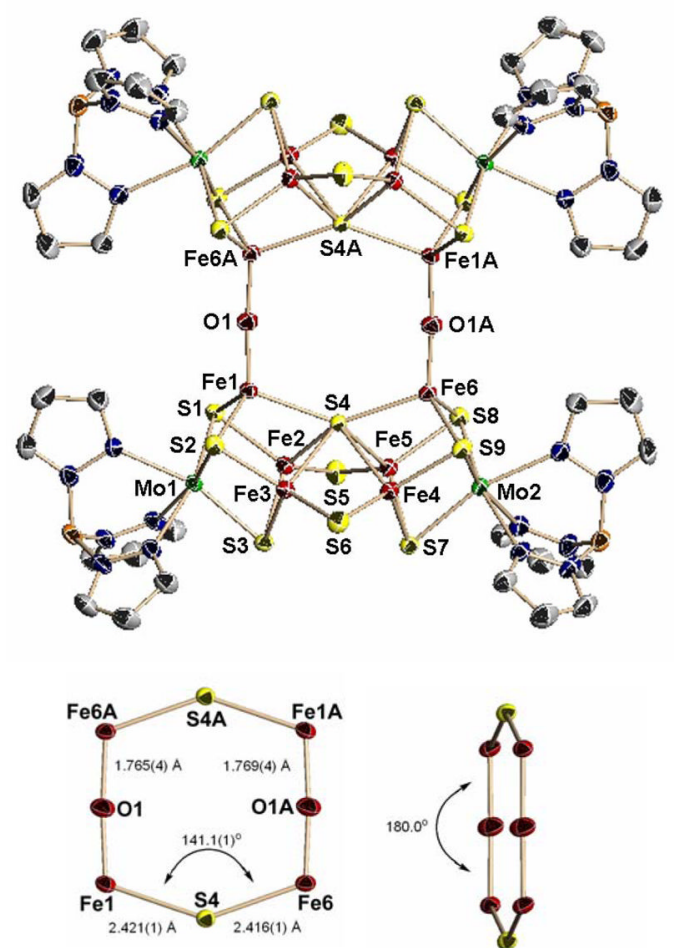

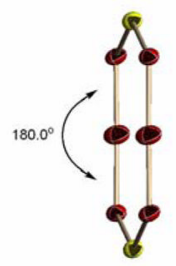

$\left\{\left[(\mathrm{Tp})_{2} \mathrm{Mo}_{2} \mathrm{Fe}_{6} \mathrm{~S}_{9} \mathrm{O}\right]_{2}\right\}^{5-}$
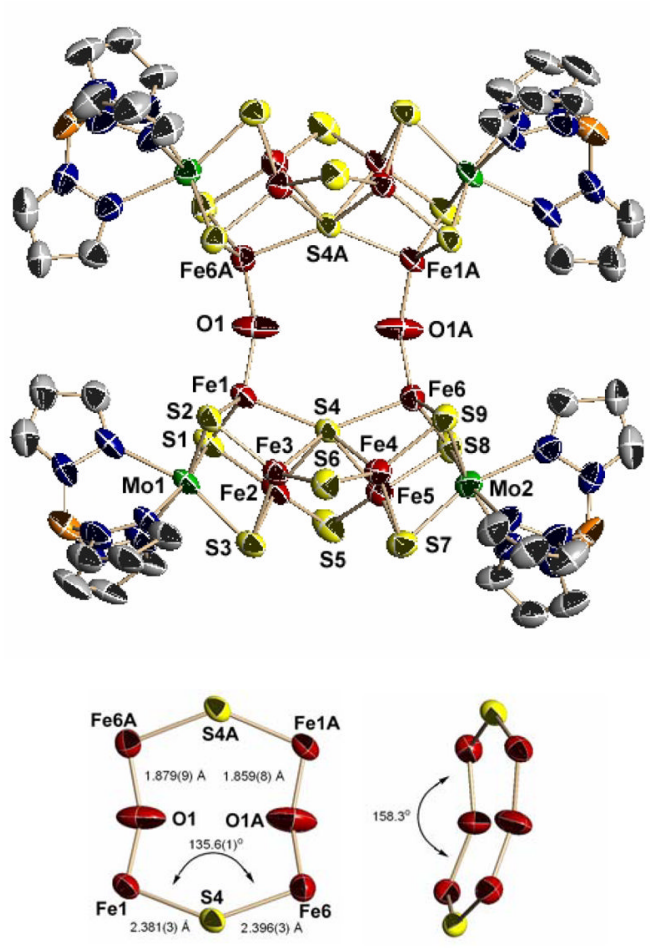

Figure 6.

Structures of the double $\mathrm{P}^{\mathrm{N}}$-type clusters $\left\{\left[(\mathrm{Tp})_{2} \mathrm{Mo}_{2} \mathrm{Fe}_{6} \mathrm{~S}_{9}\left(\mu_{2}-\mathrm{O}\right)_{2}\right]_{2}\right\}^{z}$ showing $50 \%$ probability ellipsoids and atom numbering schemes. Left: $z=4$ - with crystallographically imposed centrosymmetry. Right: $z=5$-, with a crystallographically imposed $C_{2}$ axis. Also shown are the central $\mathrm{Fe}_{4}\left(\mu_{2}-\mathrm{O}\right)_{2}\left(\mu_{6}-\mathrm{S}\right)_{2}$ rings with selected dimensions. Atoms $\mathrm{n}$ and $\mathrm{nA}$ are related by symmetry. 


\section{Table 1}

Crystallographic Data for Compounds Containing the Clusters $\left[(\mathrm{Tp})_{2} \mathrm{Mo}_{2} \mathrm{Fe}_{6} \mathrm{~S}_{9}(\mathrm{OH})(\mathrm{OC}(=\mathrm{NH}) \mathrm{Me})\left(\mathrm{H}{ }_{2} \mathrm{O}\right)\right]^{3-}$, $\left[(\mathrm{Tp})_{2} \mathrm{Mo}_{2} \mathrm{Fe}_{6} \mathrm{~S}_{9}(\mathrm{OMe})_{2}\left(\mathrm{H}_{2} \mathrm{O}\right)\right]^{3-},\left\{\left[\left((\mathrm{Tp})_{2} \mathrm{Mo}_{2} \mathrm{Fe}_{6} \mathrm{~S}_{9}\right)\left(\mu_{2}-\mathrm{O}\right)\right]_{2}\right\}^{4-}$, and $\left\{\left[\left((\mathrm{Tp})_{2} \mathrm{Mo}_{2} \mathrm{Fe}_{6} \mathrm{~S}_{9}\right)\left(\mu_{2}-\mathrm{O}\right)\right]_{2}\right\}^{5-}$

\begin{tabular}{|c|c|c|c|c|}
\hline & $\left(\mathrm{Et}_{4} \mathrm{~N}\right)_{3}[4] \cdot 4.5 \mathrm{MeCN} \cdot 2 \mathrm{H}_{2} \mathrm{O}$ & $\begin{array}{l}\left(\mathrm{Et}_{4} \mathrm{~N}\right)_{3}[5] \bullet \\
(2 \mathrm{MeCN}) \bullet \\
(5 \mathrm{MeOH}) \cdot \mathrm{H}_{2} \mathrm{O}\end{array}$ & $\left(\mathrm{Et}_{4} \mathrm{~N}\right)_{4}[6] \cdot 7 \mathrm{MeCN}$ & $\left(\mathbf{E t}_{4} \mathbf{N}\right)_{5}[7] \cdot 7 \mathrm{MeCN}$ \\
\hline Formula & $\mathrm{C}_{53} \mathrm{H}_{102.5} \mathrm{BB}_{2} \mathrm{Fe}_{6} \mathrm{Mo}_{2} \mathrm{~N}_{20.5} \mathrm{O}_{4} \mathrm{~S}_{9}$ & $\begin{array}{l}\mathrm{C}_{45} \mathrm{H}_{132} \mathrm{BB}_{2} \mathrm{Fe}_{6} \\
\mathrm{Mo}_{2} \mathrm{~N}_{16} \mathrm{O}_{8} \mathrm{~S}_{9}\end{array}$ & $\begin{array}{l}\mathrm{C}_{94} \mathrm{H}_{159} \mathrm{~B}_{4} \mathrm{~B} \\
\mathrm{Fe}_{12} \mathrm{Mo}_{4} \mathrm{~N}_{41} \mathrm{O}_{2} \mathrm{~S}_{18}\end{array}$ & $\begin{array}{l}\mathrm{C}_{102} \mathrm{H}_{175} \mathrm{~B}_{4} \mathrm{~B} \\
\mathrm{Fe}_{12} \mathrm{Mo}_{4} \mathrm{~N}_{42} \mathrm{O}_{2} \mathrm{~S}_{18}\end{array}$ \\
\hline $\begin{array}{l}\text { Formula wt } \\
\left(\mathrm{g} \cdot \mathrm{mol}^{-1}\right)\end{array}$ & 1928.20 & 1862.81 & 3569.90 & 3696.12 \\
\hline Crystal system & Orthorhombic & Monoclinic & Triclinic & Orthorhombic \\
\hline Space group & $\mathrm{P} 2_{1} 2_{1} 2_{1}$ & $\mathrm{P} 2_{1} / \mathrm{m}$ & P1 & $\mathrm{Aba} 2$ \\
\hline Temp (K) & 173 & 193 & 193 & 193 \\
\hline$Z$ & 4 & 2 & 1 & 4 \\
\hline$a,(\AA)$ & $17.551(8)$ & $15.311(4)$ & $12.869(2)$ & $35.616(4)$ \\
\hline$b,(\AA)$ & $17.721(8)$ & $17.631(5)$ & $16.927(3)$ & $26.741(3)$ \\
\hline$c,(\AA)$ & $27.948(12)$ & $17.488(5)$ & $18.823(3)$ & $16.189(2)$ \\
\hline$\alpha,(\operatorname{deg})$ & 90 & 90 & $102.506(3)$ & 90 \\
\hline$\beta,(\operatorname{deg})$ & 90 & $104.437(4)$ & $92.172(3)$ & 90 \\
\hline$\gamma,(\operatorname{deg})$ & 90 & 90 & $96.764(3)$ & 90 \\
\hline$V\left(\AA^{5}\right)$ & $8693(7)$ & $4572(2)$ & $3966.7(11)$ & 15419(3) \\
\hline $\operatorname{GOF}\left(F_{2}\right)$ & 1.050 & 0.844 & 1.100 & 1.093 \\
\hline$R_{1,}{ }^{b} w R_{2}^{c}$ & $0.0701,0.1659$ & $0.0607,0.1624$ & $0.0517,0.1385$ & $0.0714,0.1606$ \\
\hline
\end{tabular}

${ }^{a}$ Collected using Mo K $\alpha$ radiation $(\lambda=0.71073 \AA)$ radiation.

$b_{R\left(F_{O}\right)=\Sigma\left[\left(F_{O}-F_{C}\right)\right] / \Sigma\left(F_{O}\right) .}$

${ }^{c} R_{w}\left(F_{O}{ }^{2}\right)=\left\{\Sigma\left[w\left(F_{O}{ }^{2}-F_{C}{ }^{2}\right)_{2} / \Sigma\left[w\left(F_{O}{ }^{2}\right)^{2}\right]\right\}^{1 / 2}\right.$. 
Table 2

Selected Bond Lengths ( $(\hat{)})$ and Angles (deg) for Clusters 4, 5, 6, and 7

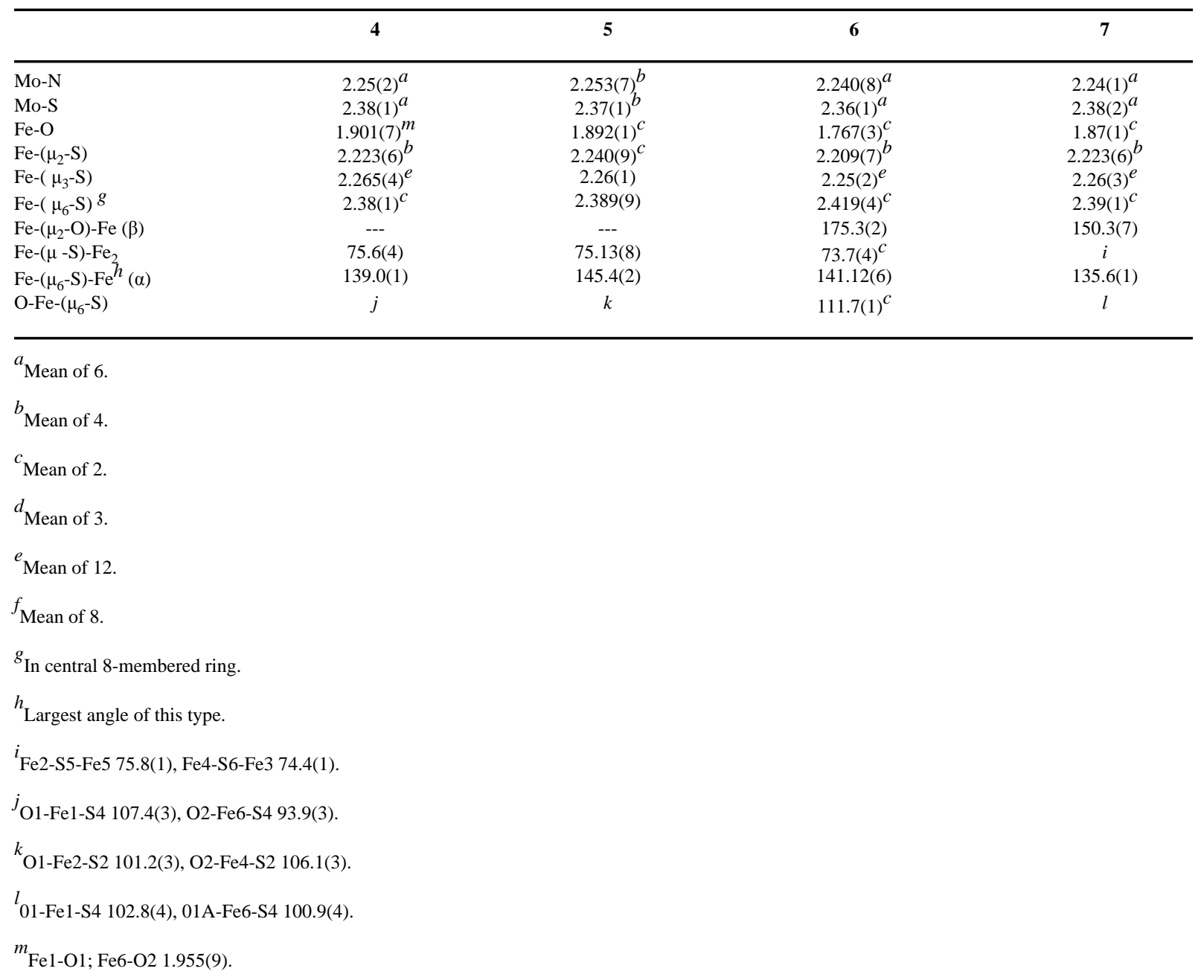


Table 3

Mössbauer Parameters for $\mathrm{P}^{\mathrm{N}}$-Type Clusters at $4.2 \mathrm{~K}$

\begin{tabular}{lcc}
\hline Cluster & $\boldsymbol{\delta}(\mathbf{m m} / \mathbf{s})$ & $\Delta \mathbf{E}_{\mathbf{Q}}(\mathbf{m m} / \mathbf{s})$ \\
\hline$\left[(\mathrm{Tp})_{2} \mathrm{Mo}_{2} \mathrm{Fe}_{6} \mathrm{~S}_{9}(\mathrm{OH})(\mathrm{OC}(=\mathrm{NH}) \mathrm{Me})\left(\mathrm{H}_{2} \mathrm{O}\right)\right]^{3-}(\mathbf{4})$ & 0.54 & 0.53 \\
{$\left[(\mathrm{Tp})_{2} \mathrm{Mo}_{2} \mathrm{Fe}_{6} \mathrm{~S}_{9}(\mathrm{OMe})_{2}\left(\mathrm{H}_{2} \mathrm{O}\right)\right]^{3-}(\mathbf{5})$} & 0.59 & 0.61 \\
{$\left[(\mathrm{Tp})_{2} \mathrm{Mo}_{2} \mathrm{Fe}_{6} \mathrm{~S}_{9}(\mathrm{SH})_{2}\right]^{3-}$} & 0.55 & 0.62 \\
$\left\{\left[(\mathrm{Tp})_{2} \mathrm{Mo}_{2} \mathrm{Fe}_{6} \mathrm{~S}_{9}\left(\mu_{2}-\mathrm{O}\right)\right]_{2}\right\}^{4-}(\mathbf{6})$ & 0.51 & 0.71 \\
$\left\{\left[(\mathrm{Tp})_{2} \mathrm{Mo}_{2} \mathrm{Fe}_{6} \mathrm{~S}_{9}\left(\mu_{2}-\mathrm{O}\right)\right]_{2}\right\}^{5-}(\mathbf{7})$ & 0.58 & 0.57 \\
\hline
\end{tabular}




\section{Chart}

Designation of Compounds and Abbreviations

\begin{tabular}{lc}
\hline$\left[(\mathrm{Tp})_{2} \mathrm{Mo}_{2} \mathrm{Fe}_{6} \mathrm{~S}_{8}\left(\mathrm{PEt}_{3}\right)_{4}\right]$ & $\mathbf{1}^{5}$ \\
{$\left[(\mathrm{Tp})_{2} \mathrm{Mo}_{2} \mathrm{Fe}_{6} \mathrm{~S}_{9} \mathrm{~F}_{2}\left(\mathrm{H}_{2} \mathrm{O}\right)\right]^{3-}$} & $\mathbf{2}^{7}$ \\
{$\left[(\mathrm{Tp})_{2} \mathrm{Mo}_{2} \mathrm{Fe}_{6} \mathrm{~S}_{9}(\mathrm{OH})_{2}\right]^{-}$} & $\mathbf{3}$ \\
{$\left[(\mathrm{Tp})_{2} \mathrm{Mo}_{2} \mathrm{Fe}_{6} \mathrm{~S}_{9}(\mathrm{OH})(\mathrm{OC}(=\mathrm{NH}) \mathrm{Me})\left(\mathrm{H}_{2} \mathrm{O}\right)\right]^{3-}$} & $\mathbf{4}$ \\
{$\left[(\mathrm{Tp})_{2} \mathrm{Mo}_{2} \mathrm{Fe}_{6} \mathrm{~S}_{9}(\mathrm{OMe})_{2}\left(\mathrm{H}_{2} \mathrm{O}\right)\right]^{3-}$} & $\mathbf{5}$ \\
$\left\{\left[(\mathrm{Tp})_{2} \mathrm{Mo}_{2} \mathrm{Fe}_{6} \mathrm{~S}_{9}\left(\mu_{2} \mathrm{O}\right)\right]_{2}\right\}^{4-}$ & $\mathbf{6}$ \\
$\left\{\left[(\mathrm{Tp})_{2} \mathrm{Mo}_{2} \mathrm{Fe}_{6} \mathrm{~S}_{9}\left(\mu_{2}-\mathrm{O}\right)\right]_{2}\right\}^{5-}$ & $\mathbf{7}$ \\
$\left\{\left[(\mathrm{Tp})_{2} \mathrm{Mo}_{2} \mathrm{Fe}_{6} \mathrm{~S}_{9}\left(\mu_{2}-\mathrm{S}\right)\right]_{2}\right\}^{5-}$ & $\mathbf{8}^{10}$ \\
$\left\{\left[(\mathrm{Tp})_{2} \mathrm{Mo}_{2} \mathrm{Fe}_{6} \mathrm{~S}_{8} \mathrm{Se}\left(\mu_{2}-\mathrm{Se}\right)\right]_{2}\right\}^{5-}$ & $\mathbf{9}^{10}$
\end{tabular}

$\mathrm{Cl}_{4}$ cat $=$ tetachlorocatecholate $(2-), \mathrm{Cp}^{*}=$ pentamethylcyclopentadienyl $(1-), \mathrm{EBDC}=$ edge-bridged double cubane, $\mathrm{FeMoco}=$ iron-molybdenum cofactor, $\mathrm{Tp}=$ hydrotris (pyrazolyl) borate(1-) 